\title{
Bulanık Analitik Hiyerarşi ve Bulanık Dematel Yöntemleri Kullanılarak Kurumsal Kaynak Planlaması Yazılım Seçimi ve Değerlendirilmesi
}

\author{
Yeşim Deniz ÖZKAN ÖZEN* $\quad$ Aydın KOÇAK**
}

\begin{abstract}
$\ddot{O} Z$
Işsletmelerde kurumsal kaynak planlaması (KKP) yatırımları stratejik bir faaliyet olup süreçlerin etkin yönetilmesini ve verimliliği etkileyen uzun dönemli bir karardır. Bu nedenle doğru KKP yazılımının seçilmesi işletmelerin rekabet avantajı sağlamaları ve sürdürülebilir olmaları için hayati bir öneme sahiptir. Fakat KKP yazılım seçimi nicel ve nitel özellikteki çok kriterli bir karar problemi olup birçok alternatif arasında seçim yapmayı gerektirmektedir. Bu çalışmada fason imalat ve makine bakım konularında faaliyet gösteren bir imalat firmasinda öncelikle sistem analizi çalışması yapılarak ihtiyaç listesi çıkarılmıştır. Sonrasında oluşan bu seçim kriterlerine göre, nihai olarak karar verilen iki yazılım firmasının uygulama yazllımlarında bulanık analitik hiyerarşi yöntemi kullanılarak seçim süreci gerçekleştirilmiştir. Buna ek olarak KKP seçimine konu olan seçim kriterlerinin etkileyen ve etkilenen ilişkileri bulanık DEMATEL yöntemi ile değerlendirilerek seçim sonrası KKP yazılımının kurulumunda rehber olacak stratejik bir yol haritası oluşturulmuştur.
\end{abstract}

Anahtar Kelimeler: Çok Kriterleri Karar Verme, Kurumsal Kaynak Planlaması, Bulanık Analitik Hiyerarşi Yöntemi, Bulanık DEMATEL Yöntemi.

Jel Sinıflandirması: C02, M11, M15.

Selection and Evaluation of Enterprise Resource Planning Software by Using Fuzzy Analytical Hierarchy Process and Fuzzy Dematel

\begin{abstract}
Investments of Enterprise Resource Planning (ERP) software is a long term strategic decision which affects the efficiency of processes in the organization. Therefore, selection of ERP software has a significant impact on gaining competitive advantage and continuing the existence. ERP selection process is a multi-criteria decision making problem, which consists many qualitative and quantitative criteria. The implementation of this study has conducted in a company, which is in the field of contract manufacturing and machine maintenance. Firstly, a system analysis study was done to have the list of specific needs of the company and then fuzzy Analytical Hierarchy Process method was used to make the selection of ERP software. In addition, to present causal relations between criteria and, fuzzy DEMATEL method was used. By using these results, strategy map was constructed to guide the company during the transition process of ERP usage.
\end{abstract}

Key Words: Multi Criteria Decision Making, Enterprise Resource Planning, Fuzzy

Analytical Hierarchy Process, Fuzzy DEMATEL

Jel Classification: C02, M11, M15.

\footnotetext{
* Araştırma Görevlisi, Yaşar Üniversitesi İşletme Fakültesi Uluslararası Lojistik Yönetimi Bölümü, yesim.ozen@yasar.edu.tr

${ }^{* *}$ Yrd. Doç. Dr., Ege Üniversitesi IIIBF İşletme Bölümü, aydin.kocak@ege.edu.tr
} 
Yeşim D. Özkan Özen \& Aydın Koçak / Bulanık Analitik Hiyerarşi ve Bulanık Dematel Yöntemleri Kullanılarak Kurumsal Kaynak Planlaması Yazılım Seçimi ve Değerlendirilmesi

\section{GíRIŞ}

Son 20 y1ldaki küreselleşme süreci, bilgi sistem ve teknolojilerindeki gelişme, üretim teknolojilerindeki ilerleme, yoğun rekabet ortamı, ürün hayat sürelerinin kısalması ve tüketici istek ve beklentilerindeki sürekli değişim işletme süreçlerini karmaşık bir hale getirmiştir. $\mathrm{Bu}$ ortamda kaynakların etkin kullanılarak maliyetlerin yönetilebilmesi için işletmelerin kurumsal kaynak planlaması (KKP) iş uygulamalarını kullanmasını zorunlu kılmıştır.

$\mathrm{KKP}$, en geniş hali ile işletmelerdeki faaliyetlerin tümünü kapsayan ve üretim, tedarik, müşteri ilişkileri, stok kontrolü, sipariş kontrolü, dağıtım gibi süreçlerin etkin bir şekilde yönetimini sağlayan ve bir yazılım ile desteklenen sistem bütünü olarak ifade edilmektedir (Wei ve Wang, 2004; Akça ve Özer, 2013). Ayrıca KKP, bütünleşik çözümler sunarak tüm kaynakların etkin şekilde kullanılmasına olanak sağlayan, işletme süreçleri içerisinde tekrar eden işleri ve verileri elimine etmeye yarayan bilgi sistemi şeklinde de tanımlanmaktadır (Amalnick ve diğerleri, 2011; Vatansever ve Uluköy, 2013). Günümüzde işletmeler gittikçe artan karmaşık süreçleri yönetmektedir. Bu süreçlerde zaman, bilgi, insan, malzeme ve makine gibi birçok kaynak kullanılmakta ve bu kaynakların maliyeti rekabet avantajı sağlamada ön plana çıkmaktadır. Bu nedenle küçük işletmelerden büyük işletmelere kadar her ölçekteki işletmede bütünsel bir çerçevede yönetim sağladığı için KKP yazılımları kullanılmaktadır.

İşletme süreçlerini destekleyecek uygun KKP yazılım seçimi sağlanacak fayda itibariyle önemli bir konudur. İlk yatırım maliyeti yüksek olan KKP yazılımları, günümüzde özellikle küçük ve orta ölçekli işletmelerin alımından çekindiği sistemlerdir (Jahanshahi ve diğerleri, 2013). Bu nedenle işletmeye uygun doğru yazılım için KKP seçim süreci önem gösterilmesi gereken bir konudur. Wei, Chien ve Wang (2005), KKP seçim sürecini yedi aşamada tanımlamıştır. Seçim süreci bir proje grubunun oluşturulması ve KKP yazılım alternatiflerinin hakkında bilgi toplanmasıyla başlamaktadır. İkinci aşamada ise KKP sisteminin özellikleri belirlenmektedir. Ardından KKP yazılımı satın alınarak gerçekleştirilmesi planlanan hedeflerin yapısı oluşturulmaktadır. Dördüncü ve beşinci basamaklarda sirasıyla KKP sistemlerinin özelliklerinin işletme amaçlarının yapısına göre değerlendirilmesi ve sistem gereksinimleri doğrultusunda KKP satıcılarına özelleştirilmiş sorular sorulması yer almaktadır. Son kısımda ise KKP yazılımlarının seçilen yöntem ile değerlendirilmesi ve seçim kararının verilmesi yer almaktadır.

KKP projelerinin başarısız olmasının temel nedenlerinden birisi süreçleri destekleyecek ve kullanıcıların bilgi ihtiyaçlarını karşılayacak doğru yazılımının seçilmemesidir. Bunun için KKP seçim sürecinde öncelikle detaylı bir sistem analizi yapılarak her seviyedeki kullanıcıların yönetim ve karar süreçlerindeki bilgi ihtiyaçları tespit edilmelidir. Sonrasında ise bu ihtiyaçları en üst seviyede karşılayacak KKP uygulamasının seçimi için yöntem belirlenmelidir. Çünkü KKP seçim problemi çok kriterli bir karar verme yapısına sahip olup birçok temel ve alt kriterlere sahip olan ve birçok KKP uygulama yazılımı alternatifine sahiptir. Bu nedenle KKP seçiminde çok kriterleri bir karar yönteminin kullanılması doğru 
yazılımın seçilmesi açısından önemlidir. Ayrıca seçime konu olan kriterlerin birbirleriyle olan ilişkilerinin ve etkilerinin anlaşılması hem seçim hem de seçim sonrası kurulum aşamasının etkinliğinde önemli bir yer tutmaktadır.

$\mathrm{Bu}$ çerçevede çalışmanın ilk aşaması olan seçim aşamasında uygulamanın yapıldığ işletmede bir analiz çalışması yapılarak ana kriterlerin altında alt kriterler ayrıntılandırılmıştır. Firmanın ölçeği göz önüne alınarak birçok KKP yazılımı arz eden firmalardan ön bir değerlendirme yapılarak iki yazılım seçilmiştir. İlk olarak uygulamanın yapıldığı işletme yetkilisi ile tüm kriterler değerlendirilmiştir. Sonrasında KKP yazılımı sağlayıcı firma yetkilileri ile birebir görüşmeler yapılarak belirlenen kriterleri karşılama düzeyleri analiz edilmiş ve bu verileri 1şığında seçim süreci bulanık analitik hiyerarşi yöntemi (BAHY) kullanılarak gerçekleştirilmiştir. Çalışmanın ikinci aşamasında ise seçim kriterlerinin birbirleri ile olan ilişkisi değerlendirilmektedir. Seçime konu olan kriterlerin seçime ve birbirlerine olan etkilerinin bilinmesi, seçim süreciyle beraber seçim sonrasındaki uygulama aşamasında da bir yol haritas sağlayacaktır. $\mathrm{Bu}$ aşamada bulanık DEMATEL yöntemi (BDY), kriterlerin birbirlerini etkileme düzeylerinin analizi için kullanılmıştır. Bununla beraber BDY sonuçları kullanılarak seçim sonrasında uygulanabilecek bir stratejik yol haritası ortaya konmuştur.

Bu çalışmada KKP seçim ve değerlendirme süreçlerinde BAHY ve BDY yöntemlerini beraber kullanıp gerçek bir problemden yola çıkarak modül bazlı detaylı alt kriterler sunarak ilgili literatüre katkı sağlamak hedeflenmiştir. Seçilen ana kriterler literatür tabanlı olarak belirlenmiş, alt kriterler ise firmanın ihtiyaçları doğrultusunda oluşturulmuştur. Bu çalışmanın diğer bir amacı ise seçime konu olan kriterlerin, seçim konusuna olan etkilerinin araştırılması ve bir yol haritasının oluşturulmasıdır.

Yapılan bu çalışmada ikinci bölümde KKP seçimi üzerine ayrıntılı bir literatür araştırması yapılarak yapılan çalışmalardaki ana kriter ve alt kriter bazında seçim kriterleri ve kullanılan yöntemler incelenmiştir. Bu bölümde ayrıca çalışmanın yöntemleri olan BAHY ve BDY'nin beraber kullanıldığı çalışmalar da ortaya konmuştur. Çalışmanın yönteminin yer aldığ 1 üçüncü bölümde BAHY ve BDY açıklanmıştır. Dördüncü bölüm olan uygulama bölümünde işletmede yapılan sistem analizi sonucunda oluşan seçim kriterlerinin belirlenmesi süreci ayrıntılandırılmıştır. Ayrıca bu bölümde BAHY ile seçim ve BDY ile de kriterlerin değerlendirme süreci gerçekleştirilmiştir. Beşinci bölümde ise uygulama bölümündeki analizler değerlendirilmiştir.

\section{I.LITERATÜR ÇALIŞMASI}

KKP seçim literatürü, seçimde kullanılan yöntem ve seçim kriterleri olarak iki temel grupta yapılmıştır. Seçim yöntemleri arasında Analitik hiyerarşi yöntemi (AHY) başta olmak üzere, TOPSIS, ANP, MOORA, PROMETHEE, DEMATEL gibi çok kriterli karar yöntemlerinin ağırlıkla kullanıldığı görülmektedir. Ayrıca seçilen kriterlerin çoğunlukla genel kriterler olduğu gözlemlenmiştir. KKP yazılım seçiminin işletmenin ihtiyaçlarına göre şekillenen bir olgu olduğu 
düşünüldüğünde sıralanan genel kriterlerin yanı sıra işletmeye özgü kriterlerin de belirlenmesi önemlidir. Ek 1'de KKP seçimi ile ilgili literatür araştırması kullanılan yöntem, ana ve alt kriterler açılarından özetlenmiştir. Bu çalışmada yaygın şekilde kullanılan ve her KKP yazılımı için değerlendirilmesi gereken firma özellikleri, maliyet, yazılım özellikleri ve kurulum süresi gibi kriterler ana kriterler olarak belirlenmekle birlikte, alt kriterlerin tümü işletme ihtiyaçları doğrultusunda özelleştirilmiş kriterlerdir.

Literatürde AHY ve DEMATEL yöntemlerinin beraber kullanılması çok sık olmamakla birlikte, çeşitli alanlarda rastlanmaktadır. Chang ve Chen (2011), RFID uygulamalarındaki başarı faktörlerinin analizini AHY ve DEMATEL ile gerçekleştirmişlerdir. Choua, Sun ve Yen (2012), bilim ve teknoloji alanında insan kaynağı seçme kriterlerinin değerlendirilmesinde BAHY'yi kriterlerin ağırlıklandırmasında, BDY'yi ise kriterler arasındaki neden-sonuç ilişkileri kurmak için kullanmışlardır. Karaoğlan ve Şahin (2016), satın alma kararları ile ilgili çalışmalarında satın alma sürecindeki faktörlerin ağırlıklarını ve birbirleriyle ilişkilerini DEMATEL yöntemiyle belirlemiş ardından bu kriterlerin işletmeler için önceliğini AHY ile değerlendirmişlerdir. Wu ve Tsai (2012) Tayvan otomotiv yedek parça endüstrisinde tedarikçi seçim kriterlerini değerlendirdikleri çalışmalarında AHY'yi kriterlerin öncelik sıralamalarını belirlemede, DEMATEL'i ise kriterlerin arasındaki nedensel ilişkiyi ortaya koymak için kullanmışlardır. Abdullah ve Zulkifli (2015) ise insan kaynakları yönetimi süreçlerinde uygulanmak üzere BAHY ve trapezoidal (ikiz kenar yamuk) bulanık sayılarının kullanıldığı BDY'yi bütünleşik bir model içerisinde kullanmışlardır. Rouhani, Ashraf ve Ashraf (2013), KKP yazılımlarının uygulama süreçlerindeki kritik başarı faktörlerinin değerlendirilmesinde BAHY ve BDY'yi bütünleşik bir yaklaşım ile kullanmışlardır. Literatürde KKP seçim probleminde BAHY ve BDY yöntemlerinin beraber kullanımına rastlanmamıştır.

\section{II. ÇALIŞMANIN YÖNTEMI}

Çalışmada seçim ve değerlendirilme yapılırken AHY ve DEMATEL yöntemlerinin beraber kullanılmasının sebebi her iki metodun da farklı amaçlara hizmet etmesidir. AHY, hiyerarşik bir yapıda ikili karşılaştırmalar ile hem kriter hem de alternatiflerin önem ilişkisini ölçerken, DEMATEL yöntemi ise kriterlerin değerlendirilmesinde önem sıralamasının yanı sıra birbirleri üzerindeki etkilerini ölçerek kriterleri etkileyen ve etkilenenler olarak ayrıştırmaktadır.

$\mathrm{Bu}$ yöntemlerin beraber kullanıldığı çalışmaların ortak özelliği AHY'nin ağırlıklandırma için kullanılması ve kriterlerin hiyerarşik düzende incelenmesi iken DEMATEL yönteminin ise kriterler arası detaylı nedensel ilişkiyi ortaya koymasıdır (Chang ve Chen, 2011; Chou, Sun ve Yen, 2011, Wu ve Tsai, 2012).

Wu ve Tsai (2012), AHY'nin sadece kriterler arası önem sıralamasını içerdiğinden kısa vadeli iyileşme fırsatları ortaya koyduğunu; DEMATEL'in ise önem sıralamasının yanı sıra kriterler arasındaki nedensel ilişkileri içermesi nedeniyle daha uzun vadeli iyileştirmelere olanak sağladığını belirtmişlerdir.

Bulanık küme teorisine dayanan bulanık mantık ilk olarak Zadeh tarafından 1965 yılında ortaya konmuştur. Bulanık mantık, iki değerli $(0,1)$ 
mantığının genişletilmiş halidir (Zadeh, 1965). Bulanık mantık ilkeleri belirsizlikleri açıklama yeteneği açısından öne çıkmıştır. Çok kriterli karar verme yöntemlerinin bulanık mantık ile entegrasyonu belirsiz durum ve yargılarda daha net karar vermeye olanak sağladığı için sıklıkla kullanılmaktadır.

Bu nedenlerden dolayı bu çalışmada yöntem olarak KKP seçim sürecinde BAHY, kriterlerin değerlendirilmesi sürecinde ise BDY kullanılmıştır.

\section{A. Bulanık Analitik Hiyerarşi Yöntemi}

AHY, karmaşık karar verme problemlerinde karar alternatifleri ve kriterlerine göre göreceli önem değerleri verilmek suretiyle çalışan çok kriterli karar verme yöntemidir. 1980'li yıllarda Thomas L. Saaty tarafindan geliştirilen bu yöntem en iyi seçeneğin belirlenmesine olanak sağlamaktadır. AHY, çok kriterli ve çok alternatifli problemlerde nicel ve nitel kriterlerin beraber değerlendirilmesine olanak sağlamaktadır. AHY, bir problemin çözümü için amaçtan başlayarak, sırasıyla ana kriterler, alt kriterler ve alternatiflere doğru hiyerarşik bir çerçeve sunmaktadır (Saaty, 1990). AHY, bir problemi küçük birleşenlere ayırarak her hiyerarşide öncelikleri oluşturmak için ikili karşılaştırmalar yapmaktadır (Saaty, 1986). Böylece AHY, karmaşık durumların bileşenlerini ve değişkenlerini hiyerarşik düzende ifade ederek her alternatifin karşılaştırmalı önem derecelerine ilişkin nicel yargılara sayısal değerler atama ve sonuçta öncelik düzeyleri belirleyip alternatifler arasından seçim yapmaya olanak sağlamaktadır. Literatürde yaygın kullanımının yanı sıra, AHY ikili karşılaştırmalar yaparken kesin sayılar kullanmasından ve belirsizlik durumunda etkin bir değerlendirme konusundaki eksiklikleri nedeniyle dolayı birçok yazar tarafindan eleştirilmiştir (Kwong ve Bai, 2003; Kahraman, Cebeci ve Ruan, 2004; Ayağ ve Özdemir, 2006). Bu eleştirilerin başında, karar vericilerin nitel kriterleri değerlendirmede kesin yargilar kullanmalarının güçlüğü gelmektedir (Dağdeviren, 2007). Bu zorluğu aşmak ve ikili değerlendirmeler esnasında daha net sonuçlar almak adına AHY yaklaşımı bulanık mantık ile entegre edilerek BAHY kullanılmaktadır (Leung ve Cao, 2000). Lien ve Liang (2005), Cebeci (2009), Vatansever ve Uluköy (2013), Kılıç, Zaim ve Delen (2014) çalışmalarında BAHY'yi KKP seçiminde kullanmışlardır.

AHY'de bulanık üçgensel sayıların kullanımı ilk olarak Van Laarhoven ve Pedrycg tarafından gerçekleştirilmesinin ardından konu ile ilgili olarak birçok farklı yaklaşım ortaya atılmakla birlikte bu çalışmada Chang'ın Genişletilmiş Analiz Yöntemi kullanılmıştır. Chang'ın yönteminde üçgensel bulanık sayılar öncelikle ikili karşılaştırmalar için kullanılmakta ardından genişletilmiş analiz yöntemi kullanılarak ikili karşılaştırmaların sentetik değerleri hesaplanıp bulanık sayılar karşılaştırılarak ağırlık vektörleri ortaya konmaktadır (Chang, 1996). Genişletilmiş Analiz Yönteminin temel özelliği klasik AHY'ye benzemesi ve diğer yöntemlerden nispeten daha kolay olarak nitelendirilmesidir (Tolga ve diğerleri, 2005)

$\mathrm{Bu}$ çalışmada bulanık sayıların üçgensel olarak değerlendirilmesi aşağıdaki aşamalar izlenerek gerçekleştirilmiştir. 
Adım 1: Bulanık sayılardan oluşan dilsel ölçeğin belirlenmesi

Bulanık sayıların üçgensel olarak değerlendirilmesinde Liou ve Wang (1992), Chang (1996), Abdel Kader ve Dugdale (2001) farklı ölçekler kullanmışlardır. $\mathrm{Bu}$ çalışmada kullanılan Chang'ın ölçeğindeki kullanılan değişkenler ve karşılıkları olan bulanık ifadeler Tablo 1'de gösterilmektedir.

Tablo 1. BAHY Dilsel Değişkenler ve Bulanık Karşılıkları

\begin{tabular}{ll}
\hline Dilsel Önem Derecesi & Bulanık Ölçek \\
\hline Eşit Derecede Önemli & $(1,1,1)$ \\
Biraz Önemli & $(1 / 2,1,3 / 2)$ \\
Önemli & $(1,3 / 2,2)$ \\
Çok Önemli & $(3 / 2,2,5 / 2)$ \\
Kesinlikle Önemli & $(2,5 / 2,3)$ \\
\hline
\end{tabular}

Adım 2: Ölçüt i’ye göre bulanık sentetik mertebe değerinin belirlenmesi

$\mathrm{S}_{\mathrm{i}}=\sum_{j=1}^{m} \boldsymbol{M}_{g_{i}}^{j} \otimes\left[\sum_{i=1}^{n} \sum_{j=1}^{m} M_{g_{i}}^{j}\right]^{-1}$

Adım 3: $M_{2}=\left(l_{2}, m_{2}, u_{2}\right) \geq M_{1}=\left(l_{1}, m_{1}, u_{1}\right)$ olas1lık derecesi, $V\left(M_{2} \geq M_{1}\right)=\sup _{x \geq y}\left[\min \left(\mu_{M I}(\mathrm{x}), \mu_{M 2}(\mathrm{y})\right)\right]$

şeklinde tanımlanır. $\mathrm{M}_{1}$ ve $\mathrm{M}_{2}$ üçgensel konveks bulanık sayılar olmak üzere,

$V\left(M_{2} \geq M_{1}\right)=\operatorname{hgt}\left(M_{1} \cap M_{2}\right)=\mu_{M 2}(d)=\left\{\begin{array}{lr}1, & m_{2} \geq m_{1} \\ 0, & l_{1} \geq u_{2} \\ \frac{l_{1}-u_{2}}{\left(m_{2}-u_{2}\right)-\left(m_{1}-l_{1}\right)}, & \text { diğer }\end{array}\right.$

(3) ifadesi elde edilir (Kahraman ve diğerleri, 2004). $V\left(M_{2} \geq M_{1}\right)$ ifadesi, M1 ve M2 üçgensel bulanık sayılarının kesişim ordinatını göstermektedir. M1 ve M2'nin kiyaslanabilmesi için $V\left(M_{2} \geq M_{1}\right)$ ve $V\left(M_{1} \geq M_{2}\right)$ değerlerinin hesaplanması gerekmektedir.

Adım 4: Konveks bulanık bir sayının k adet konveks bulanık sayılardan büyük olabilmesinin olabilirlik derecesi,

$V\left(M \geq M_{1}, M_{2} \ldots M_{k}\right)=V\left(M \geq M_{1}\right)$ ve $V\left(M \geq M_{2}\right) \cap \ldots \cap V\left(M \geq M_{k}\right)=\min V(M$ $\left.\geq M_{i}\right), i=1,2, ., k(4)$

şeklinde tanımlanır. Burada $i=\{1,2, \ldots ., k\}$ için $d^{\prime}\left(A_{1}\right)=\min V\left(S_{i} \geq S_{k}\right) i=\{1,2, \ldots, k\}$ ise $k \neq i$ için ağırlık vektörü, $W^{\prime}=\left(d^{\prime}\left(A_{1}\right), d^{\prime}\left(A_{2}\right), \ldots, d^{\prime}\left(A_{n}\right)\right)^{T}(5)$ şeklinde elde edilir.

Ağırlık vektörü normalize edilerek, $W=\left(d\left(A_{1}\right), d\left(A_{2}\right), \ldots, d\left(A_{n}\right)\right)^{T}$ (6) vektörü elde edilir. Bu vektör artık bulanık sayı içermemektedir. 
Bu çalışmada BAHY kullanılarak KKP yazılım seçimi yukarıda açıklanan bulanık yöntem doğrultusunda aşağıdaki aşamalar uygulanarak gerçekleştirilmiştir:

Aşama 1: Karar probleminin ana kriter, alt kriter ve alternatiflerinden oluşan hiyerarşik yapısının geliştirilmesi.

Aşama 2: Ana kriterlerin değerlendirilmesi

Ana kriterlerin ikili karşılaş̧tırmalarının Eşitlik 1,2,3,4,5 ve 6 kullanılarak değerlendirilmesi ve normalize ağırlık vektörünün hesaplanması.

Aşama 3: Alt kriterlerin değerlendirilmesi

Alt kriterlerin ikili karşılaştırmalarının Eşitlik 1,2,3,4,5 ve 6 kullanılarak değerlendirilmesi ve normalize ağırlık vektörünün hesaplanması

Aşama 4: Alternatiflerin değerlendirilmesi

Alternatiflerin tüm alt kriterlere göre değerlendirilmesi ve Eşitlik 1,2,3,4,5 ve 6 kullanılarak değerlendirilmesi ve normalize ağırlık vektörünün hesaplanmas1

Aşama 5: Aşama 2, 3 ve 4 sonuçlarının değerlendirilmesi

Aşama 2, 3 ve 4 sonucunda elde edilen normalize ağırlık vektörleri kullanılarak toplam ağırlık vektörünün elde edilmesi ve alternatifler arasında karar vermeye yarayacak olan toplam ağırlık değerlerinin hesaplanması.

\section{B. Bulanık DEMATEL}

Çok kriterli karar verme yöntemlerinden biri olan DEMATEL (Decision Making Trial and Evaluation Laboratory) yöntemi, karmaşık ilişkiler içeren yapıları matris yapıs1 ve skorlar yardımıyla değerlendirmeye olanak sağlamaktadır. DEMATEL'in en önemli özelliği incelenen faktörler arasında nedensel ilişkiler kurarak, bu faktörleri etkileyenler ve etkilenenler olmak üzere sinıflandırmasıdır (Tzeng, Chiang ve Li, 2007). DEMATEL yöntemi ilk olarak 1973 yılında Cenevre Araştırma Merkezi içerisinde yer alan The Battelle Memorial Enstitüsünde yapılan bir çalışmada uygulanmış olup, karmaşık ilişkileri araştırmak ve nedensel ilişkileri ortaya koymak amacıyla bir çok çalışmada kullanılmaktadır (Wu ve Lee, 2007; Tsai ve Chou, 2008; Aksakal ve Dağdeviren, 2010; Yang ve Tzeng, 2011; Altan ve Aydın, 2015).

Karmaşık neden sonuç ilişkilerini görsel hale getirerek anlamlı ve kullanılabilir sonuçlar ortaya koymayı hedefleyen DEMATEL yönteminde, bu ilişkilerin etkileşim miktarını ölçmek oldukça zordur. Bu durumun temel sebebi dilsel ifadelerin nicel özellik taşımasıdır. (Chang, Chang ve $\mathrm{Wu}, 2011$ ) $\mathrm{Bu}$ nedenle DEMATEL yöntemini bulanık ortama uyumlu hale getirerek dilsel ifadelerle değerlendirilen çalışmalarda araştırmanın güvenilirliği için fayda sağlamaktadır (Büyüközkan ve Çiftçi, 2012). özetlenmiş̧tir.

BDY’nin aşamaları Wu ve Lee (2007) tarafından aşağıdaki gibi

Adım 1: Çalışma amaçlarının belirlenmesi ve karar grubunun kurulması

Adım 2: Değerlendirilecek kriterlerin belirlenmesi ve bulanık skalanın oluşturulması.

$\mathrm{Bu}$ çalışmada kriterlerin değerlendirilmesinde beş adet dilsel değişken kullanılmıştır. Kullanılan değişkenler ve karşılıkları olan bulanık ifadeler Tablo 2'de gösterildiği gibidir. 
Tablo 2. Dilsel Değişkenler ve Bulanık İfadeler

\begin{tabular}{cc}
\hline Dilsel İfade & Bulanık İfade \\
\hline Çok Fazla Etkili & $(0.75,1.0,1.0)$ \\
Fazla Etkili & $(0.5,0.75,1.0)$ \\
Az Etkili & $(0.25,0.5,0.75)$ \\
Çok Az Etkili & $(0,0.25,0.5)$ \\
Etkisiz & $(0,0,0.25)$ \\
\hline
\end{tabular}

Adım 3: Belirlenen kriterlerin karar vericiler tarafından ikili ilişkiler şeklinde değerlendirilmesi

Karar vericilerin $C=\left\{C_{i} \mid i=1,2, . ., n\right\}$ kriterleri arasındaki ilişkiyi ölçmek için ikili karşılaştırma matrisi oluşturulmaktadır.

Adım 4: CFCS metodu kullanılarak durulaştırma işlemi yapılır ve $Z=\left\lfloor z_{i j}\right\rfloor_{n x n}$ matrisin oluşturulur.

CFCS yöntemi Opracovic ve Tzeng tarafindan ortaya konan ve bulanık sayılardan oluşan verilerin kesin sayılara dönüştürülmesinde kullanılan bir durulaştırma yöntemidir. Toplam 5 aşamadan oluşan bu yöntem aşağıdaki gibi uygulanmaktadır:

(1) Normalizasyon

$$
x l_{i j}^{k}=\left(l_{i j}^{k}-\min l_{i j}^{k}\right) / \Delta_{\min }^{\max },
$$

$$
x m_{i j}^{k}=\left(m_{i j}^{k}-\min l_{i j}^{k}\right) / \Delta_{\min }^{\max },
$$

$$
x r_{i j}^{k}=\left(r_{i j}^{k}-\min l_{i j}^{k}\right) / \Delta_{\min }^{\max } ;
$$

$$
\Delta_{\min }^{\max }=\max r_{i j}^{k}-\min l_{i j}^{k} \text {. }
$$

(2) Sol (l) ve sağ (r) taraftaki normalize değerlerin hesaplanması:

$$
\begin{aligned}
& x l s_{i j}^{k}=x m_{i j}^{k} /\left(1+x m_{i j}^{k}-x l_{i j}^{k}\right), \\
& (10) \\
& x r s_{i j}^{k}=x r_{i j}^{k} /\left(1+x r_{i j}^{k}-x m_{i j}^{k}\right) .
\end{aligned}
$$

(3) Toplam normalize edilen kesin değerin hesaplanmasi:

$$
\left.x_{i j}^{k}=\left\lfloor x l s_{i j}^{k}\left(1-x l s_{i j}^{k}\right)+x r s_{i j}^{k} x r s_{i j}^{k}\right] / \mid 1-x l s_{i j}^{k}+x r s_{i j}^{k}\right\rfloor
$$

(4) Kesin değerin hesaplanması: 
$z_{i j}^{k}=\min l_{i j}^{k}+x_{i j}^{k} \Delta_{\min }^{\max }$.

(13)

(5) Kesin değerlerin birleştirilmesi:

$z_{i j}^{k}=\frac{1}{p}\left(z_{i j}^{1}+z_{i j}^{2}+\cdots+z_{i j}^{p}\right)$.

Adım 4: Normalize edilmiş direkt ilişki matrisinin oluşturulması

$\mathrm{X}=\left[\mathrm{x}_{\mathrm{ij}}\right]_{\mathrm{nxn}}$ and $0 \leq \mathrm{x}_{\mathrm{ij}} \leq 1$,

$X=s \cdot Z$

$s=\frac{1}{\max _{1 \leq i \leq n} \sum_{j=1}^{n} z_{i j}}$,

$i, j=1,2, \cdots, n$.

(16)

Adım 5: Toplam ilişki matrisinin oluşturulması

$T=X(I-X)^{-1}$

(17)

I birim matrisi ifade etmektedir.

Adım 6: Yapısal modelin oluşturulması ve sonuçların değerlendirilmesi

$T=t_{i j}, \quad i, j=1,2, \ldots, n$,

$$
\begin{aligned}
& D=\sum_{j=1}^{n} t_{i j}, \\
& R=\sum_{i=1}^{n} t_{i j},
\end{aligned}
$$

formülleri ile D-R ve D+R değerleri hesaplanır. D değeri, toplam ilişki matrisinde satır değerlerinin toplamını, $\mathrm{R}$ değeri ise sütun değerleri toplamını ifade etmektedir.

Nedensel ilişki matrisinde $D-R$ ve $D+R$ değerleri eşitlik 18 ve 19 yardımıyla hesaplanır. Nedensel ilişki matrisinde $D+R$ değeri yatay eksende yer alır ve kriterler arası önem ilişkisini belirtmektedir. D-R değeri ise dikey eksende yer alarak kriterlerin birbiri ile ilişkilerini ifade etmektedir. Bir kriter için D-R değeri pozitif ise kriterin etkileyen grubunda yer aldığını, negatif ise etkilenen grubunda yer aldığını ifade etmektedir.

\section{III.UYGULAMA}

Bu bölümde uygulamanın yapıldığ 1 işletme hakkında kısa bir bilgi verilerek işletmede toplanan bilgiler ışığında KKP yazılım seçiminin kriterleri ve 
alternatifleri açıklanmıştır. Sonrasında ise KKP yazılım seçiminde BAHY ve kriterlerin değerlendirilmesinde ise BDY uygulamaları ayrıntılı olarak açıklanmıştır.

\section{A. İşletme Hakkında Genel Bilgiler}

Çalışmada KKP yazılım seçimi, İzmir Kemalpaşa'da yer alan ve faaliyetleri fason üretim ve bakım onarım hizmetleri olmak üzere iki ana gruba ayrılan bir işletme için gerçekleştirilmiştir. Fason üretim yapısı incelendiğinde, üretim sipariş üzerine gerçekleştirilmektedir ve ürün çeşitliliği oldukça yüksektir. Üretilmesi istenen parçalar işletmeye teknik resim olarak ulaşmakta ya da tarif sonucu öncelikle teknik resimler çizilmekte ardından üretim gerçekleşmektedir. Bakımonarım faaliyetleri ise çeşitli sektörlerdeki fabrikaların üretim hatlarında bakım, onarım ve revizyon hizmetlerini içermektedir. Numune ya da teknik resim üzerinden parça üretiminin dışında hasarlı parça ve sistemler üzerinde çalışmalar da yapılmaktadır.

\section{B. KKP Yazlım Seçim Kriterleri}

KKP yazılım seçimi için kullanılan kriterler ikinci bölümde açıklanan literatür çalışması ve işletme yöneticileri ve çalışanları ile gerçekleştirilen görüşmeler sonucunda yapılan ihtiyaç analizi doğrultusunda ortaya konmuştur. Uygulama çalışmasında işletmede bir sistem analizi çalışması gerçekleştirilerek bir KKP yazılımından beklentileri ve bilgi ihtiyaçları analiz edilerek bir ihtiyaç listesi oluşturulmuştur. Sonuç olarak yazılım seçiminde kullanılan kriterler aşağıda belirtildiği gibi yazılım özellikleri, maliyet, kurulum süresi ve firmanın özellikleri olmak üzere dört ana kriter altında toplanmıştır. Her bir ana kriter, analiz sonucunda ortaya çıkan ihtiyaçlar çerçevesinde alt kriterler belirlenmiştir.

\section{- Yazılım Özellikleri (K1)}

- Makine Bakım Modülü $\left(\mathbf{K}_{11}\right)$ : İşletmenin yaşadığ problemlerden bir tanesi planlı bakımların gerçekleştirilememesi ve bakımın ancak bozulma sonucu durması ile gerçekleştiriliyor olmasıdır. Makine bakım modülünden temel beklentiler aşağıdaki gibidir.

$\checkmark$ Planlı bakımlar için uyarı sisteminin oluşturulması,

$\checkmark$ Makine yedek parça yönetiminin gerçekleştirilmesi: İşletmenin üretim yapısı gereği makine bakımlarında iki çeşit eylem gerçekleştirilmektedir. Bunlar parçanın tamamen değiştirilmesi ya da değişiklik yapılmayarak onarıma gidilmesidir. Yazılımdan beklenen girilen veriler 1şı̆̆ında yedek parça yönetiminin raporlanması ve kullanıc1ları bilgilendirmesidir.

$\checkmark$ Makine bakımında iş gücü planlamasının yapılması: Personel bazında makine bakımı için atamaların yapılması, raporlar içerisinde bakım için gereken sürenin adam/saat cinsinden ifade edilmesi.

- Üretim Modülü $\left(\mathbf{K}_{12}\right)$ :

$\checkmark$ Makine verimlilik raporu: Makinelerin üretilen parçalar, kullanılan takım ve sorumlu operatörlerin eşleşmeleri yapılarak makine bazında 
verimlilik raporlarının sunulması. Verimlilik raporuna göre makine ve takımların birbirine atanması.

$\checkmark$ Talep tahminine dayalı üretim planlamast: İşletmede fason üretim tarafında sipariş üzerinde çalışılsa da geçmiş siparişler incelenerek rutine yakın siparişlerin saptanması. Bu veriler ile talep tahmini yapılmas1 ve üretim planına yansitılması.

$\checkmark$ Farklı ölçü birimlerinde stok yönetimi ve raporlanması: Mevcut sistemde satın alma birimi ile stok birimi birbirinden farklıdır. Satın alma kilogram cinsinden gerçekleşmekte ihtiyaç uzunluk olarak belirlenip kilogram cinsine çevrilmektedir. Yazılımdan temel beklenti satın alma ve stok yönetiminde farklı birimlerde stok tutmaya ve uygun veriler girildiğinde birimleri birbirine dönüştürmeye ve gerekli raporları sunmaya olanak sağlamalıdır.

$\checkmark$ Üretim takip raporları: Üretim sonu kayıtlarının detaylı raporlanmasını içermektedir. Fire, hurda ve boşa çalışma oranları, tezgah-takım-ürüne göre üretim takip raporlanı ve birim/işlem sürelerinin raporlanması ve dashboard yardımıyla kullanıcıya sunulmas1.

$\checkmark$ İstatistiksel süreç kontrolü alt yapısı

$\checkmark$ Stok uyarı sistemi: Stok uyarı sistemi makine parçaları (yedek parça), hammadde ve nihai ürünler için ayrı ayrı raporlanmalıdır. Ayrıca yeniden sipariş noktası, alt-üst limit, $\mathrm{ABC}$ analizi gibi yöntemlerin uygulanabilir olması ve raporlanması beklenmektedir.

$\checkmark$ Personel bazında verimlilik raporlart: Personel - makine atamas1 ardından çıtı sayısı, kalite oranları gibi verilerin performans değerlendirmelerinde kullanılmak üzere raporlanması.

$\checkmark$ Esnek ürün ă̆acl yapısı: Sipariş bazlı bir üretim gerçekleştirildiğinden dolayı benzer ürünlerin ürün ağacının oluşturulmasında esnek ve hızlı bir alt yapı gerekliliğii.

$\checkmark \quad$ Teknik resimlerden ürün ağacına dönüş̧ürrme alt yapısı

- Tedarik/Satın Alma (K13):

$\checkmark$ Tedarikçi performans değerlendirmesi: Teslim zaman1, kalite oran1, maliyetler ve ürün bilgisi doğrultusunda tedarikçilerinin performans değerlendirmesinde kullanılacak raporlar.

$\checkmark$ Tedarikçi izleme platformu: Benzer ürün gruplarının tedarikçilerinin birbiri ile kıyaslanabilmesi için satın alması yapılan ürünün birim başına maliyeti, zamana göre zam oranları ve teslimat bilgilerini içeren kıyaslama raporları.

$\checkmark$ Potansiyel tedarikçilerin sinıflandırılması: Henüz alım yapılmayıp görüşmeler gerçekleştirilen potansiyel tedarikçileri ürün grupları, fiyat aralıklarına ve ödeme şekillerine göre sınıflandırılması. Yeni tedarikçi ihtiyacı durumunda tek ekrandan gerekli anahtar kelimeler girilerek tedarikçi seçiminin gerçekleştirilmesi.

- Satış $\left(K_{14}\right)$ : 
Yeşim D. Özkan Özen \& Aydın Koçak / Bulanık Analitik Hiyerarşi ve Bulanık Dematel Yöntemleri Kullanılarak Kurumsal Kaynak Planlaması Yazılım Seçimi ve Değerlendirilmesi

$\checkmark$ Sipariş performans değerlendirmesi: Sipariş takibinin müşteri bazında detaylı raporlanması. Gecikmelerin, ürünlerin ve maliyetlerin rapor içerisinde yer alması.

$\checkmark$ Satış sonrası reddedilen ürünlerin takibi: Siparişlerin ret sebebi, ret miktarı ve reddin maliyetinin rapor içerisinde yer alması (Ret maliyeti geri dönen ürünün birim maliyetinden yola çıarak hesaplanmaktadır ve maliyet muhasebesi modülünün doğru şekilde çalıştığ1 varsayılmaktadır).

- Müşteri Bakım Yönetimi (K $\left.\mathbf{K}_{15}\right)$ :

$\checkmark$ Müşteri bazında bakım planlarının raporlanması: İşletmenin iki temel çalışma alanından biri olan müşteri bakım-onarım faaliyetleri için çalışmaya giden ekip, gereken malzemeler ve işlemin tamamlanma süresini içeren bilgilerin raporlanması. Bakım-onarım faaliyetleri genellikle tahmin edilemez bir trend izlemekte, bu sebeple geçmişe dönük faturalar doğrultusunda bakıma gidilen hattın potansiyel ihtiyaçlarının belirlenmesi, üretim ya da satın alma gerekiyorsa bunların planlamaya yansitılması ve fiyatlandırmanın bu bilgiler 1şığında gerçekleştirilmesi.

- Müşteri ilişkileri $\left(\mathbf{K}_{16}\right)$ :

$\checkmark$ Müşteri bilgi sistemi: Müşterilerin sipariş verme oranları, sipariş miktarları ve ödeme bilgilerine göre müşterilerin performanslarının değerlendirilmesine olanak sağlayan raporların düzenlenmesi. $\mathrm{Bu}$ raporlar doğrultusunda satış iptalleri ya da vade çeşitlenmesinin gerçekleşmesi.

- Maliyet Muhasebesi $\left(K_{17}\right)$ :

$\checkmark$ Fiili maliyet raporu: Tezgâh ve personel bazında birim maliyetlerin hesaplanması ve raporlanması (bitmiş ürünün maliyeti).

$\checkmark$ Standart maliyetlendirme raporu: Sipariş bazlı bir üretim yapısı olduğundan dolayı sipariş teklifinin hazırlanmasını destekleyecek bir alt yap1

$\checkmark$ Hazırlı maliyeti raporu: Standart ürün üretimi olmadığı için hazırlık süreci üretimin önemli bir kısmını oluşturuyor olduğundan dolayı ürüne göre hazırlık maliyetleri raporlanmalı.

$\checkmark$ Kullanılan takım maliyeti raporu: Üretim gerçekleşirken makine dışında takımlarda kullanılıyor. Takım maliyetlerinin toplam maliyete eklenmesi ihtiyacı bulunmaktadir.

- Finans $\left(K_{18}\right)$ :

$\checkmark$ Borç riski uyarı sistemi: İşletmenin tedarikçilerine olan borçlarının detaylı raporları ve vadesi dolmaya yakın uyarı sisteminin devreye girmesi ve kullanıc1ları bilgilendirmesi.

$\checkmark$ Müşteri ödeme riski uyarl sistemi: Borç ödeme konusunda sorunlu müşterilerin bir sonraki siparişlerinde kullanılmak üzere sistem tarafindan uyarılması. 
- Esneklik (K $\left.\mathbf{K}_{\mathbf{1 9}}\right)$ : Orta ve uzun vadede işletmenin faaliyet alanının farklılaşması durumunda yazılımım yeni koşullara kolayca ve düşük maliyetler uyum sağlaması. Ayrıca ara yüz, raporlanma ve uyarı ihtiyaçlarının kolayca karşılanması.

\section{- Maliyet (K2)}

- Modül maliyeti $\left(\mathbf{K}_{21}\right)$ : Uygulamanın gerçekleştiği işletmenin ihtiyaçlarına göre yazılımda bulunması gereken modüller; üretim planlama, malzeme yönetimi, finans/muhasebe, tedarik zinciri yönetimi, maliyet muhasebesi, makine bakım olarak belirlenmiştir.

- Danışmanlık maliyeti $\left(K_{22}\right)$

- Geliştirme maliyeti $\left(K_{23}\right)$

- Bakım maliyeti $\left(K_{24}\right)$

- Ödeme Şekli $\left(K_{25}\right)$

- Kurulum Süresi (K3): Sözleşme yapıldıktan sonra canlıya geçene kadarki geçen süreyi ifade etmektedir.

- Firma Özellikleri (K4)

- Referans $\left(\mathbf{K}_{\mathbf{4 1}}\right)$ : Yazılım firmasının hizmet verdiği müşterileri ve bu müşterilerden alınan geri dönüşler.

- Destek hizmetlerindeki yaygınlık $\left(\mathbf{K}_{\mathbf{4 2}}\right)$ : Firmanın destek hizmetlerinin bölgesel olarak ulaşılabilir olması ve sorun durumunda kısa zamanda müdahale edilebilmesi. Ayrıca firmanın ana merkezden mi yoksa çözüm ortağı ile mi destek sağlayacağı.

- Eğitim ve danışmanlık $\left(\mathbf{K}_{\mathbf{4 3}}\right)$ : Firmanın ana merkez ya da çözüm ortağı ile destek sağlaması durumlarında eğitim ve danışmanlık hizmetlerinin kalitesi ve hızı.

- Satış sonrası hizmetler $\left(\mathbf{K}_{44}\right)$ : Firmanın satış sonraki süreçlerdeki tutumu, hızı ve ihtiyaç karşılama düzeyi.

Ek 2'de yukarıda belirtilen kriterlerin hiyerarşisi gösterilmektedir.

\section{Alternatiflerin Belirlenmesi}

Kriterler belirlendikten sonra hem işletmenin ölçeği ve ihtiyaçlarına göre hem de yazılım firmalarının kabiliyeti ve özellikleri göz önüne alınarak KKP yazılımı sunan firmalar ön elemeye tutularak A ve B olarak adlandırılan iki alternatife karar verilmiştir.

\section{Bulanık AHY ile KKP Seçimi}

Veri toplama bölümünde ayrıntılı açıklandığı gibi işletmede yapılan analiz sonucunda KKP seçim problemine ilişkin hiyerarşik yapı EK-2'de gösterilmektedir. $\mathrm{Bu}$ hiyerarşik yapı üzerinden ilk olarak ana kriterler ve alt kriterler dilsel bulanık ifadeler yardımıyla ikili olarak karşılaştırılmıştır. Daha sonra her iki alternatif bütün alt kriterler açısından değerlendirilmiştir. Bu değerlendirmeler III-A bölümde açıklanan bulanık sayıların üçgensel olarak değerlendirme aşamalarına göre yapılmıştır. Ana kriterlerin değerlendirilmesi aşağıda adım adım anlatılarak alt kriterlerin ve alternatiflerin değerlendirilmesi bu aşamalara göre gerçekleştirilerek tüm değerlendirme sonuçları özetlenmiştir.

Adım 1: Ana kriter matrisinin oluşturulması 
Bu aşamada Tablo 3'de görüldüğü gibi ana kriterlerin dilsel değerlendirme sonuçlarının bulanık ölçeğe dönüştürülerek ana kriter matrisi oluşturulmuştur.

Tablo 3. Ana Kriter Değerlendirme Matrisi

\begin{tabular}{|l|l|l|l|l|l|l|l|l|l|l|l|l|}
\cline { 2 - 13 } \multicolumn{1}{c|}{} & \multicolumn{3}{|c|}{ K1 } & \multicolumn{3}{c|}{ K2 } & \multicolumn{3}{c|}{ K3 } & \multicolumn{3}{c|}{ K4 } \\
\hline K1 & 1,00 & 1,00 & 1,00 & 0,50 & 1,00 & 1,50 & 2,00 & 2,50 & 3,00 & 1,50 & 2,00 & 2,50 \\
\hline K2 & 0,67 & 1,00 & 2,00 & 1,00 & 1,00 & 1,00 & 2,00 & 2,50 & 3,00 & 1,50 & 2,00 & 2,50 \\
\hline K3 & 0,33 & 0,40 & 0,50 & 0,33 & 0,40 & 0,50 & 1,00 & 1,00 & 1,00 & 0,50 & 1,00 & 1,50 \\
\hline K4 & 0,40 & 0,50 & 0,67 & 0,40 & 0,50 & 0,67 & 0,67 & 1,00 & 2,00 & 1,00 & 1,00 & 1,00 \\
\hline
\end{tabular}

Adım 2: Ana kriter matrisinin sentetik mertebe değerinin belirlenmesi Bu adımda Eşitlik 1 kullanılarak Tablo 4'te verilen ana kriter matrisinin sentetik mertebe değerleri hesaplanmıştır.

Tablo 4. Ana Kriterlerin Sentetik Mertebe Değerleri

\begin{tabular}{|c|c|c|c|}
\hline K1 & 0,205 & 0,346 & 0,541 \\
\hline K2 & 0,212 & 0,346 & 0,574 \\
\hline K3 & 0,089 & 0,149 & 0,236 \\
\hline K4 & 0,101 & 0,160 & 0,293 \\
\hline
\end{tabular}

Adım 3: Ana kriter matrisinin olabilirlik derecesinin, ağırlık vektörünün ve normalize ağırlık vektörünün belirlenmesi

Eşitlik 2-3-4-5 ve 6 kullanılarak Tablo 5 'te gösterilen değerler elde edilmiştir.

Tablo 5. Ağırlık ve Normalize Ağırlık Vektörü

\begin{tabular}{|c|c|c|c|c|c|c|}
\hline & K1 & K2 & K3 & K4 & $\begin{array}{c}\text { Ağırlık } \\
\text { Vektörü }\end{array}$ & $\begin{array}{c}\text { Normalize } \\
\text { Ağırlık } \\
\text { Vektörü }\end{array}$ \\
\hline K1 & - & 1,00 & 1,00 & 1,00 & 1,00 & 0,41 \\
\hline K2 & 1,00 & - & 1,00 & 1,00 & 1,00 & 0,41 \\
\hline K3 & 0,14 & 0,11 & - & 0,93 & 0,11 & 0,05 \\
\hline K4 & 0,32 & 0,30 & 1,00 & - & 0,30 & 0,13 \\
\hline
\end{tabular}

Adım 4: Adım 1, 2 ve 3'de gerçekleştirilen işlemlerin alt kriterler ve alternatifler için tekrarlanması.

Tüm bu adımlar sonucunda elde edilen sonuçlar Tablo 6'da özetlenmiştir. 
Tablo 7. Karar Tablosu

\begin{tabular}{|c|c|c|c|c|c|}
\hline \multirow[t]{2}{*}{$\begin{array}{c}\text { ANA } \\
\text { KRİTER }\end{array}$} & \multirow{2}{*}{$\begin{array}{l}\text { ANA KRİTER } \\
\text { ÖNEM } \\
\text { DERECESI }\end{array}$} & \multirow[t]{2}{*}{$\begin{array}{l}\text { ALT } \\
\text { KİRITER }\end{array}$} & \multirow{2}{*}{$\begin{array}{l}\text { ALT KRİTER } \\
\text { ÖNEM } \\
\text { DERECESİ }\end{array}$} & \multicolumn{2}{|c|}{$\begin{array}{l}\text { ALTERNATÍFLERİN } \\
\text { ÖNCELIK } \\
\text { DEĞERLERİ }\end{array}$} \\
\hline & & & & $\mathbf{A}$ & B \\
\hline \multirow{9}{*}{$\mathrm{K} 1$} & \multirow{9}{*}{0,41} & $\mathrm{~K}_{11}$ & 0,10 & 0,50 & 0,50 \\
\hline & & $\mathrm{K}_{12}$ & 0,18 & 0,68 & 0,32 \\
\hline & & $\mathrm{K}_{13}$ & 0,11 & 0,68 & 0,32 \\
\hline & & $\mathrm{K}_{14}$ & 0,10 & 0,50 & 0,50 \\
\hline & & $\mathrm{K}_{15}$ & 0,14 & 0,50 & 0,50 \\
\hline & & $\mathrm{K}_{16}$ & 0,08 & 0,68 & 0,32 \\
\hline & & $\mathrm{K}_{17}$ & 0,13 & 0,68 & 0,32 \\
\hline & & $\mathrm{K}_{18}$ & 0,08 & 0,50 & 0,50 \\
\hline & & $\mathrm{K}_{19}$ & 0,07 & 0,68 & 0,32 \\
\hline \multirow{5}{*}{$\mathrm{K} 2$} & \multirow{5}{*}{0,41} & $\mathrm{~K}_{21}$ & 0,95 & 0,68 & 0,32 \\
\hline & & $\mathrm{K}_{22}$ & 0,00 & 0,50 & 0,50 \\
\hline & & $\mathrm{K}_{23}$ & 0,03 & 0,50 & 0,50 \\
\hline & & $\mathrm{K}_{24}$ & 0,03 & 0,50 & 0,50 \\
\hline & & $\mathrm{K}_{25}$ & 0,00 & 0,50 & 0,50 \\
\hline K3 & 0,05 & - & - & 0,50 & 0,50 \\
\hline \multirow{4}{*}{ K4 } & \multirow{4}{*}{0,13} & $\mathrm{~K}_{41}$ & 0,25 & 0,50 & 0,50 \\
\hline & & $\mathrm{K}_{42}$ & 0,25 & 0,50 & 0,50 \\
\hline & & $\mathrm{K}_{43}$ & 0,25 & 0,50 & 0,50 \\
\hline & & $\mathrm{K}_{44}$ & 0,25 & 0,68 & 0,32 \\
\hline
\end{tabular}

Tablo 6. Özet Tablo

\begin{tabular}{|c|c|c|c|c|c|}
\hline & $\begin{array}{c}\text { Yazllım } \\
\text { Özellikleri } \\
\text { (K1) }\end{array}$ & Maliyet (K2) & $\begin{array}{l}\text { Kurulum } \\
\text { Süresi (K3) }\end{array}$ & $\begin{array}{c}\text { Firma } \\
\text { Özellikleri } \\
(\text { K4) }\end{array}$ & $\begin{array}{c}\text { Toplam } \\
\text { Ağırlık } \\
\text { Vektörü }\end{array}$ \\
\hline A & 0,62 & 0,67 & 0,50 & 0,55 & 0,62 \\
\hline B & 0,38 & 0,33 & 0,50 & 0,45 & 0,38 \\
\hline
\end{tabular}

\section{E. Bulanık DEMATEL ile Kriterlerin Değerlendirilmesi}

$\mathrm{Bu}$ bölümde KKP seçiminde ele alınan ana kriterlerin ve BAHY uygulaması sonucunda önemi ortaya çıkan ve KKP projelerinin başarısını doğrudan etkileyen yazılım özellikleri kriterlerinin birbirleri ile etkileşimini ortaya koymak için BDY uygulaması gerçekleştirilmiştir. Aşağıdaki adımlar uygulanarak ana kriterlerin BDY uygulaması gerçekleştirilerek yazılım özellikleri kriterleri de bu adımlar ile uygulanarak sonuçları açıklanmıştır.

Adım 1: Ana kriterlerin bulanık dilsel ifade matrisinin oluşturulması İşletme yöneticisi tarafindan ana kriterlerin değerlendirmesi sonucunda Tablo 2'deki bulanık ifadeler kullanılarak Tablo 8'deki değerlendirme matrisi oluşturulmuştur. Bu değerlendirmede kriterlerin ikili olarak birbirlerini ne ölçüde etkilediği sorgulanmıştır. 
Yeşim D. Özkan Özen \& Aydın Koçak / Bulanık Analitik Hiyerarşi ve Bulanık Dematel Yöntemleri Kullanılarak Kurumsal Kaynak Planlaması Yazılım Seçimi ve Değerlendirilmesi

Tablo 8. Ana Kriterlerin Bulanık Dilsel İfadeler ile Değerlendirilmesi

\begin{tabular}{|c|c|c|c|c|c|c|c|c|c|c|c|c|}
\hline & \multicolumn{3}{|c|}{ K1 } & \multicolumn{3}{c|}{ K2 } & \multicolumn{3}{c|}{ K3 } & \multicolumn{3}{c|}{ K4 } \\
\hline K1 & 0 & 0 & 0,25 & 0,75 & 1 & 1 & 0,5 & 0,75 & 1 & 0 & 0 & 0,25 \\
\hline K2 & 0 & 0 & 0,25 & 0 & 0 & 0,25 & 0 & 0 & 0,25 & 0,25 & 0,5 & 0,75 \\
\hline K3 & 0,25 & 0,5 & 0,75 & 0,25 & 0,5 & 0,75 & 0 & 0 & 0,25 & 0 & 0 & 0,25 \\
\hline K4 & 0,5 & 0,75 & 1 & 0,25 & 0,5 & 0,75 & 0,75 & 1 & 1 & 0 & 0 & 0,25 \\
\hline
\end{tabular}

Adım 2: Ana kriterlerin direkt ilişki matrisi oluşturulması

$\mathrm{Bu}$ aşamada durulaştırma yöntemlerinden biri olan ve 7-14 eşitlikleri kullanarak uygulanan CFCS yöntemi sonrasında Tablo 9'te gösterilen direkt ilişki matrisi oluşturulmuştur. $\mathrm{Bu}$ çalışmanın yapısı gereği yalnızca bir uzman görüşü kullanıldığ 1 için CFCS yöntemi uygulanırken 5. Adım olan kesin değerlerin birleştirilmesi aşaması atlanmıştır (Eşitlik 14).

Tablo 9. Direkt İlişki Matrisi

\begin{tabular}{|l|l|l|l|l|}
\hline \multicolumn{1}{|c|}{$\mathbf{Z}$} & \multicolumn{1}{|c|}{ K1 } & \multicolumn{1}{|c|}{ K2 } & \multicolumn{1}{c|}{ K3 } & \multicolumn{1}{c|}{ K4 } \\
\hline K1 & 0,0333 & 0,967 & 0,733 & 0,033 \\
\hline K2 & 0,0333 & 0,033 & 0,033 & 0,5 \\
\hline K3 & 0,5 & 0,5 & 0,033 & 0,033 \\
\hline K4 & 0,7333 & 0,5 & 0,967 & 0,033 \\
\hline
\end{tabular}

Adım 3: Ana kriterlerin normalize edilmiş direkt ilişki matrisi oluşturulması

Bu aşamada Eşitlik 15 ve 16 kullanılarak Tablo 10'da gösterilen normalize edilmiş direkt ilişki matrisi oluşturulmuştur.

Tablo 10. Normalize Edilmiş Direkt İlişki Matrisi

\begin{tabular}{|c|c|c|c|c|}
\hline $\mathbf{X}$ & K1 & K2 & K3 & K4 \\
\hline K1 & 0 & 0,433 & 0,328 & 0,015 \\
\hline K2 & 0,015 & 0 & 0,015 & 0,224 \\
\hline K3 & 0,224 & 0,224 & 0 & 0,015 \\
\hline K4 & 0,328 & 0,224 & 0,433 & 0 \\
\hline
\end{tabular}

Adım 4: Toplam ilişki matrisinin oluşturulması

Normalize edilmiş direkt ilişki matrisinin oluşturulmasının ardından Eşitlik 17 kullanılarak Tablo 11'te gösterilen toplam ilişki matrisi oluşturulmuştur.

Tablo 11. Toplam İlişki Matrisi

\begin{tabular}{|c|c|c|c|c|}
\hline $\mathbf{T}$ & K1 & K2 & K3 & K4 \\
\hline K1 & 0,17 & 0,649 & 0,467 & 0,17 \\
\hline K2 & 0,145 & 0,162 & 0,18 & 0,265 \\
\hline K3 & 0,302 & 0,415 & 0,155 & 0,115 \\
\hline K4 & 0,547 & 0,653 & 0,694 & 0,165 \\
\hline
\end{tabular}


Adım 5: Yapısal modelin oluşturulması

Son olarak BDY uygulamasının 5. Adımında yapısal modelin oluşturulması ve için Eşitlik 18-19 kullanılarak Tablo 12'de verilen $D-R$ ve $D+R$ değerleri hesaplanmıştır. Ardından bu değerler kullanılarak Şekil 1.'de gösterilen nedensel ilişki grafiği oluşturulmuş̧tur.

Tablo 12. Ana Kriterlerin D-R ve D+R Değerleri

\begin{tabular}{|l|c|c|c|c|}
\cline { 2 - 5 } \multicolumn{1}{c|}{} & $\mathrm{K} 1$ & $\mathrm{~K} 2$ & $\mathrm{~K} 3$ & $\mathrm{~K} 4$ \\
\hline $\mathrm{D}+\mathrm{R}$ & 2,621 & 2,631 & 2,483 & 2,773 \\
\hline $\mathrm{D}-\mathrm{R}$ & 0,292 & $-1,128$ & $-0,508$ & 1,345 \\
\hline
\end{tabular}

Şekil 1. Ana Kriterlerin Nedensel İlişki Grafiği

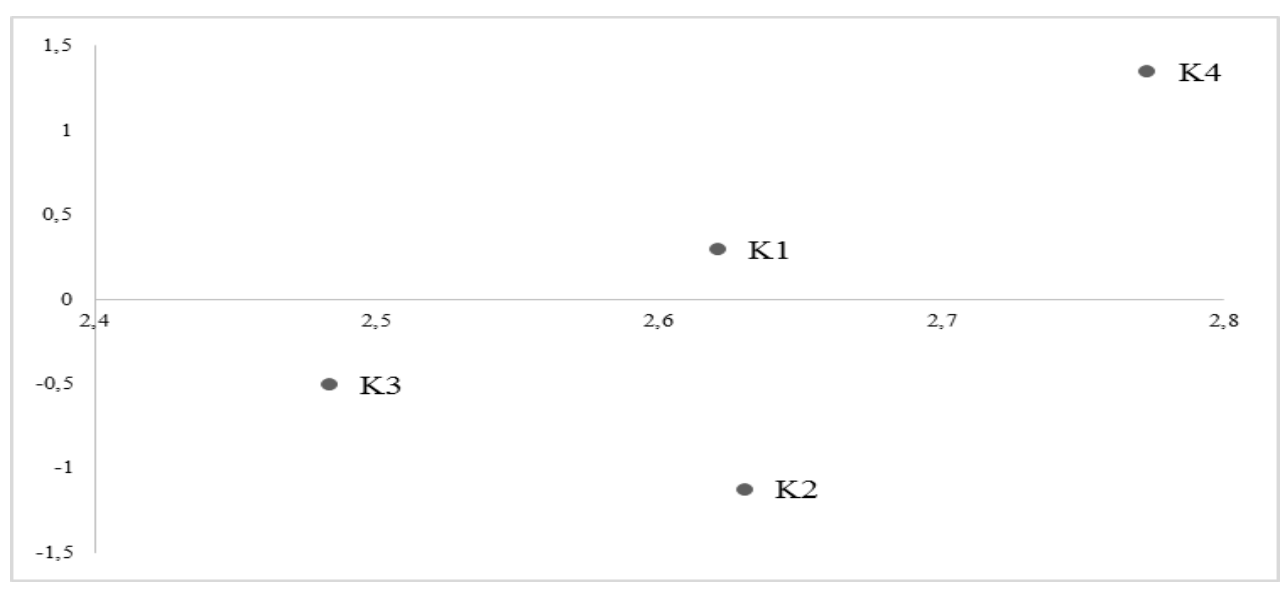

( K1: Yazılım Özellikleri, K2: Maliyet: K3: Kurulum Süresi, K4: Firma Özellikleri)

Yazılım özelliklerinin değerlendirilmesinde de yukarıda açılana ana kriterlerin değerlendirilmesinde kullanılan adımlar izlenmiştir. Yazılım özelliklerinin bulanık dilsel ifadelerle değerlendirilmesi sonucu oluşturulan değerlendirme matrisi Tablo 13'de gösterilmektedir.

Tablo 13. Yazılım Özellikleri Direkt İlişki Matrisi

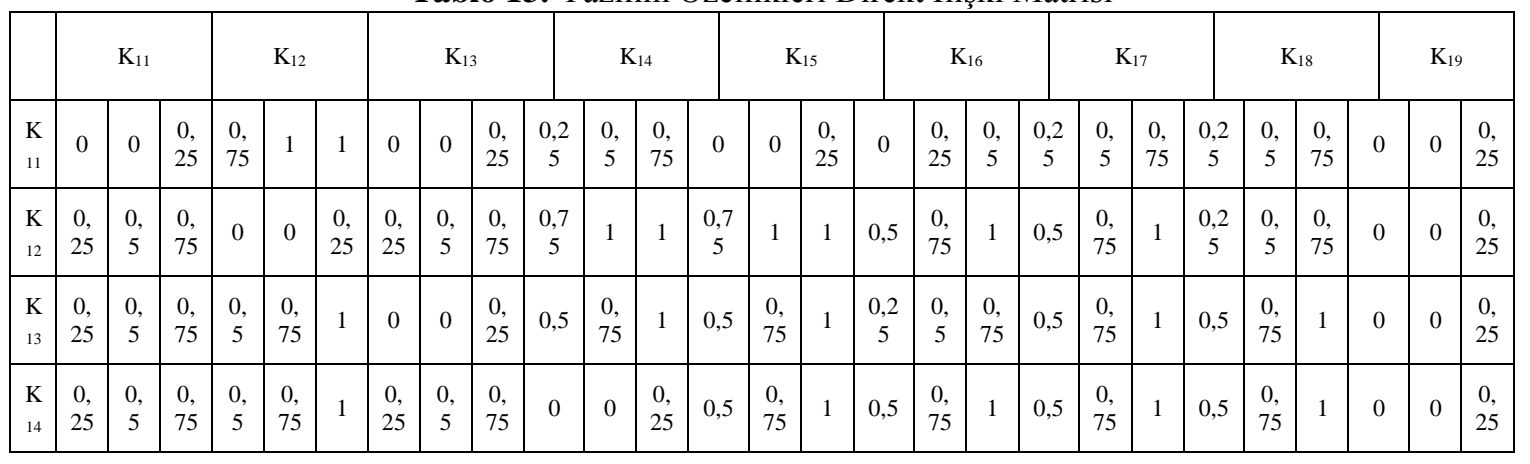


Yeşim D. Özkan Özen \& Aydın Koçak / Bulanık Analitik Hiyerarşi ve Bulanık Dematel Yöntemleri Kullanılarak Kurumsal Kaynak Planlaması Yazılım Seçimi ve Değerlendirilmesi

\begin{tabular}{|c|c|c|c|c|c|c|c|c|c|c|c|c|c|c|c|c|c|c|c|c|c|c|c|c|c|c|c|}
\hline $\begin{array}{l}\text { K } \\
15\end{array}$ & $\begin{array}{c}0, \\
25\end{array}$ & $\begin{array}{l}0, \\
5\end{array}$ & $\begin{array}{c}0, \\
75\end{array}$ & $\begin{array}{l}0 \\
5\end{array}$ & $\begin{array}{c}0 \\
75\end{array}$ & 1 & $\begin{array}{l}0, \\
5\end{array}$ & $\begin{array}{c}0, \\
75\end{array}$ & 1 & $\begin{array}{c}0,7 \\
5\end{array}$ & 1 & 1 & 0 & 0 & $\begin{array}{c}0, \\
25\end{array}$ & 0,5 & $\begin{array}{c}0, \\
75\end{array}$ & 1 & 0,5 & $\begin{array}{l}0, \\
75\end{array}$ & 1 & 0,5 & $\begin{array}{c}0, \\
75\end{array}$ & 1 & 0 & $\begin{array}{c}0, \\
25\end{array}$ & $\begin{array}{l}0 \\
5\end{array}$ \\
\hline $\begin{array}{l}\text { K } \\
16\end{array}$ & 0 & $\begin{array}{c}0, \\
25\end{array}$ & $\begin{array}{l}0, \\
5\end{array}$ & $\begin{array}{c}0, \\
25\end{array}$ & $\begin{array}{l}0, \\
5\end{array}$ & $\begin{array}{c}0 \\
75\end{array}$ & $\begin{array}{l}0, \\
25\end{array}$ & $\begin{array}{l}0 \\
5\end{array}$ & $\begin{array}{c}0, \\
75\end{array}$ & 0,5 & $\begin{array}{c}0, \\
75\end{array}$ & 1 & 0,5 & $\begin{array}{c}0, \\
75\end{array}$ & 1 & 0 & 0 & $\begin{array}{c}0, \\
25\end{array}$ & $\begin{array}{c}0,2 \\
5\end{array}$ & $\begin{array}{c}0, \\
5\end{array}$ & $\begin{array}{c}0, \\
75\end{array}$ & $\begin{array}{c}0,2 \\
5\end{array}$ & $\begin{array}{l}0, \\
5\end{array}$ & $\begin{array}{c}0, \\
75\end{array}$ & $\begin{array}{c}0,2 \\
5\end{array}$ & $\begin{array}{c}0, \\
5\end{array}$ & $\begin{array}{c}0, \\
75\end{array}$ \\
\hline $\begin{array}{l}\text { K } \\
17\end{array}$ & $\begin{array}{l}0, \\
5\end{array}$ & $\begin{array}{c}0, \\
75\end{array}$ & 1 & $\begin{array}{c}0, \\
75\end{array}$ & 1 & 1 & $\begin{array}{l}0, \\
5\end{array}$ & $\begin{array}{c}0, \\
75\end{array}$ & 1 & $\begin{array}{c}0,2 \\
5\end{array}$ & $\begin{array}{c}0, \\
5\end{array}$ & $\begin{array}{c}0, \\
75\end{array}$ & 0,5 & $\begin{array}{c}0, \\
75\end{array}$ & 1 & $\begin{array}{c}0,2 \\
5\end{array}$ & $\begin{array}{l}0, \\
5\end{array}$ & $\begin{array}{c}0, \\
75\end{array}$ & 0 & 0 & $\begin{array}{c}0, \\
25\end{array}$ & 0,5 & $\begin{array}{l}0, \\
75\end{array}$ & 1 & 0 & 0 & $\begin{array}{l}0, \\
25\end{array}$ \\
\hline $\begin{array}{l}\text { K } \\
18\end{array}$ & $\begin{array}{l}0, \\
5\end{array}$ & $\begin{array}{c}0, \\
75\end{array}$ & 1 & $\begin{array}{l}0, \\
5\end{array}$ & $\begin{array}{c}0 \\
75\end{array}$ & 1 & $\begin{array}{l}0, \\
5\end{array}$ & $\begin{array}{c}0, \\
75\end{array}$ & 1 & 0,5 & $\begin{array}{c}0, \\
75\end{array}$ & 1 & 0,5 & $\begin{array}{c}0, \\
75\end{array}$ & 1 & $\begin{array}{c}0,2 \\
5\end{array}$ & $\begin{array}{l}0, \\
5\end{array}$ & $\begin{array}{c}0, \\
75\end{array}$ & 0,5 & $\begin{array}{l}0, \\
75\end{array}$ & 1 & 0 & 0 & $\begin{array}{c}0, \\
25\end{array}$ & 0 & 0 & $\begin{array}{l}0, \\
25\end{array}$ \\
\hline $\begin{array}{l}\text { K } \\
19\end{array}$ & $\begin{array}{l}0, \\
25\end{array}$ & $\begin{array}{l}0, \\
5\end{array}$ & $\begin{array}{l}0, \\
75\end{array}$ & $\begin{array}{c}0, \\
25\end{array}$ & $\begin{array}{l}0, \\
5\end{array}$ & $\begin{array}{l}0, \\
75\end{array}$ & 0 & $\begin{array}{l}0, \\
25\end{array}$ & $\begin{array}{l}0, \\
5\end{array}$ & 0 & $\begin{array}{l}0, \\
25\end{array}$ & $\begin{array}{l}0, \\
5\end{array}$ & $\begin{array}{c}0,2 \\
5\end{array}$ & $\begin{array}{l}0, \\
5\end{array}$ & $\begin{array}{l}0, \\
75\end{array}$ & $\begin{array}{c}0,2 \\
5\end{array}$ & $\begin{array}{l}0, \\
5\end{array}$ & $\begin{array}{c}0, \\
75\end{array}$ & $\begin{array}{c}0,2 \\
5\end{array}$ & $\begin{array}{l}0, \\
5\end{array}$ & $\begin{array}{c}0, \\
75\end{array}$ & 0 & 0 & $\begin{array}{l}0, \\
25\end{array}$ & 0 & 0 & $\begin{array}{c}0, \\
25\end{array}$ \\
\hline
\end{tabular}

Ana kriterler için uygulanan BDY adımları yazılım özellikleri kriterleri için de izlenerek sırasıyla Tablo 14'de verilen toplam ilişki matrisi ve Tablo 15'de verilen D-R ve D+R değerleri hesaplanmıştır. Elde edilen değerler ile Şekil 2'de gösterilen nedensel ilişki grafiği oluşturulmuştur.

Tablo 14. Yazılım Özelliklerinin Toplam İlişki Matrisi

\begin{tabular}{|l|l|l|l|l|l|l|l|l|l|}
\hline $\mathrm{T}$ & $\mathrm{K}_{11}$ & $\mathrm{~K}_{12}$ & $\mathrm{~K}_{13}$ & $\mathrm{~K}_{14}$ & $\mathrm{~K}_{15}$ & $\mathrm{~K}_{16}$ & $\mathrm{~K}_{17}$ & $\mathrm{~K}_{18}$ & $\mathrm{~K}_{19}$ \\
\hline $\mathrm{K}_{11}$ & 0,316 & 0,585 & 0,325 & 0,5 & 0,405 & 0,386 & 0,468 & 0,44 & 0,078 \\
\hline $\mathrm{K}_{12}$ & 0,611 & 0,722 & 0,617 & 0,854 & 0,811 & 0,69 & 0,766 & 0,69 & 0,136 \\
\hline $\mathrm{K}_{13}$ & 0,592 & 0,813 & 0,511 & 0,79 & 0,75 & 0,63 & 0,74 & 0,7 & 0,126 \\
\hline $\mathrm{K}_{14}$ & 0,589 & 0,808 & 0,593 & 0,668 & 0,747 & 0,662 & 0,736 & 0,696 & 0,129 \\
\hline $\mathrm{K}_{15}$ & 0,649 & 0,89 & 0,686 & 0,898 & 0,703 & 0,727 & 0,81 & 0,763 & 0,179 \\
\hline $\mathrm{K}_{16}$ & 0,498 & 0,696 & 0,536 & 0,711 & 0,679 & 0,486 & 0,634 & 0,594 & 0,193 \\
\hline $\mathrm{K}_{17}$ & 0,643 & 0,87 & 0,643 & 0,778 & 0,767 & 0,645 & 0,64 & 0,716 & 0,13 \\
\hline $\mathrm{K}_{18}$ & 0,642 & 0,835 & 0,642 & 0,809 & 0,765 & 0,644 & 0,758 & 0,597 & 0,129 \\
\hline $\mathrm{K}_{19}$ & 0,404 & 0,523 & 0,365 & 0,47 & 0,48 & 0,43 & 0,474 & 0,373 & 0,079 \\
\hline
\end{tabular}

( $\mathrm{K}_{11}$ : Makine Bakım Modülü, $\mathrm{K}_{12}$ : Üretim Modülü, $\mathrm{K}_{13}$ : Tedarik/Satın Alma, $\mathrm{K}_{14}$ : Satış, $\mathrm{K}_{15}$ : Müşteri Bakım Yönetimi, $\mathrm{K}_{16}$ : Müşteri İlişskileri, $\mathrm{K}_{17}$ : Maliyet Muhasebesi, $\mathrm{K}_{18}$ : Finans, $\mathrm{K}_{19}$ : Esneklik)

Tablo 15. Yazılım Özelliklerinin D-R ve D+R Değerleri

\begin{tabular}{|l|c|c|c|c|c|c|c|c|c|}
\hline & $\mathrm{K}_{11}$ & $\mathrm{~K}_{12}$ & $\mathrm{~K}_{13}$ & $\mathrm{~K}_{14}$ & $\mathrm{~K}_{15}$ & $\mathrm{~K}_{16}$ & $\mathrm{~K}_{17}$ & $\mathrm{~K}_{18}$ & $\mathrm{~K}_{19}$ \\
\hline D+R & 8,447 & 12,639 & 10,570 & 12,106 & 12,412 & 10,329 & 11,858 & 11,390 & 4,777 \\
\hline D-R & $-1,441$ & $-0,845$ & 0,733 & $-0,850$ & 0,197 & $-0,274$ & $-0,194$ & 0,253 & 2,420 \\
\hline
\end{tabular}


Şekil 2. Yazılım Özelliklerinin Nedensel İlişki Grafiği

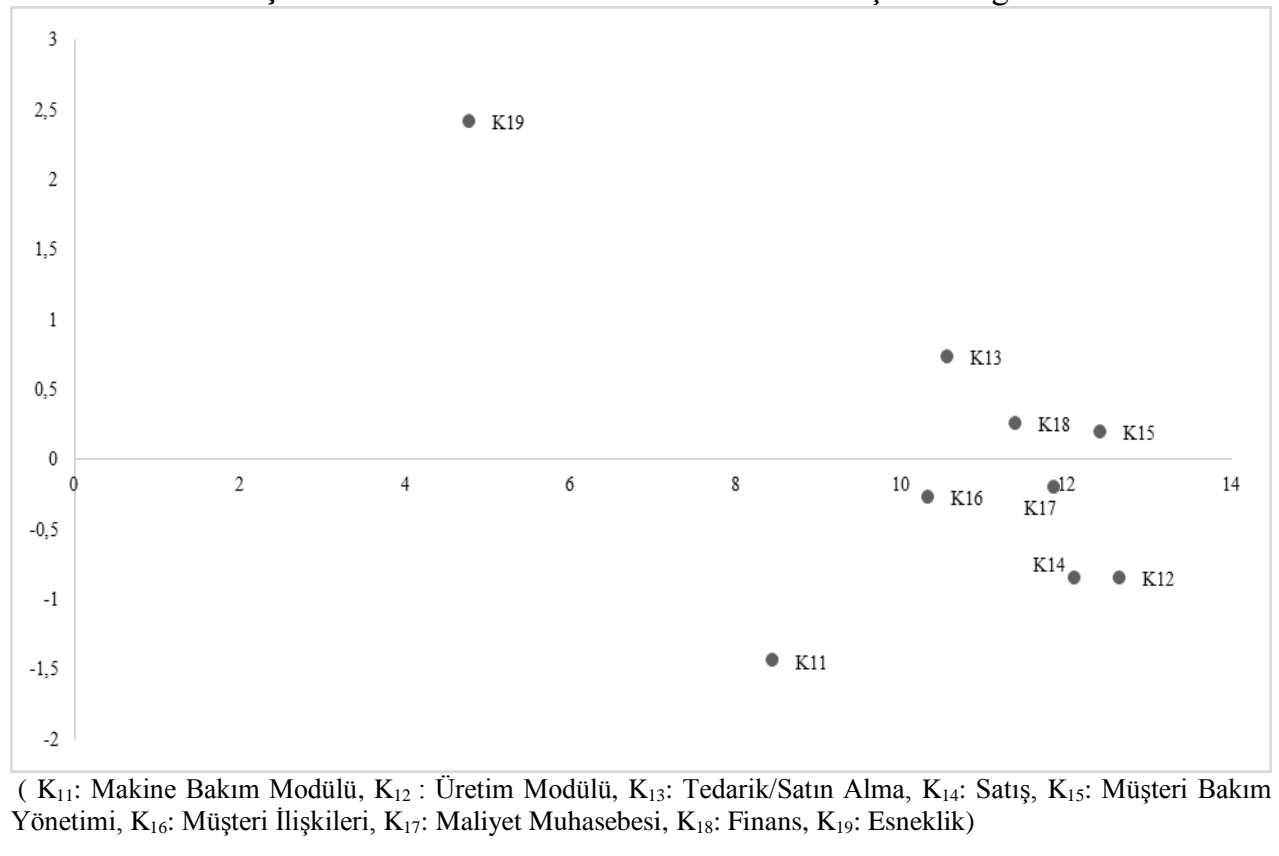

BDY uygulaması sonucunda elde edilen bulguları değerlendirmede strateji haritası olarak bilinen ve kurumsal karne yöntemi ile ilişkili bir araç kullanılabilmektedir. Strateji haritasının temel özelliği nedensel ilişkileri ortaya koyması ve bu ilişkiler doğrultusunda etkin stratejilerin benimsenmesinde karar desteği sağlamasıdır ( $\mathrm{Wu}, 2012)$. BDY, nedensel ilişkileri detaylı olarak analiz etmekte kullanılan yapısı itibariyle strateji haritası oluşturmak için en uygun yöntemlerden biri olarak nitelendirilmektedir (Jassbi ve diğerleri, 2011)

BDY uygulamasından elde edilen sonuçlar doğrultusunda kriterlerin arasındaki nedensel ilişkiyi strateji haritasında gösterebilmek için öncelikle az etkiye sahip ilişkiler elenmelidir (Kumar ve Dash, 2016). Bu işlem için Yang ve diğerleri (2008) toplam ilişki matrisindeki tüm değerlerin ortalamasının alarak bir eşik değer $(\alpha)$ hesaplanmasını önermiştir. Buna göre eşik değer altında kalan değerler düşük ilişkiye sahip olduğu için strateji haritasında gösterilmeyecektir. $\mathrm{Bu}$ çalışmada strateji haritası, işletme kararında ve KKP kurulumunda büyük önem taşıdığı düşünülen yazılım özellikleri için hazırlanmıştır. Tablo 14 'de verilen yazılım özelliklerinin toplam ilişki matrisine göre eşik değeri $(\alpha) 0,58$ olarak hesaplanmıştır. Buna göre yazılım özelliklerinin nedensel ilişkilerini içeren strateji haritası Şekil 3’te gösterilmektedir. Esneklik kriteri eşit değerin altında kaldığından dolayı değerlendirmeye alınmamıştır. 
Şekil 3: Yazılım Özellikleri Kriterleri Strateji Haritası

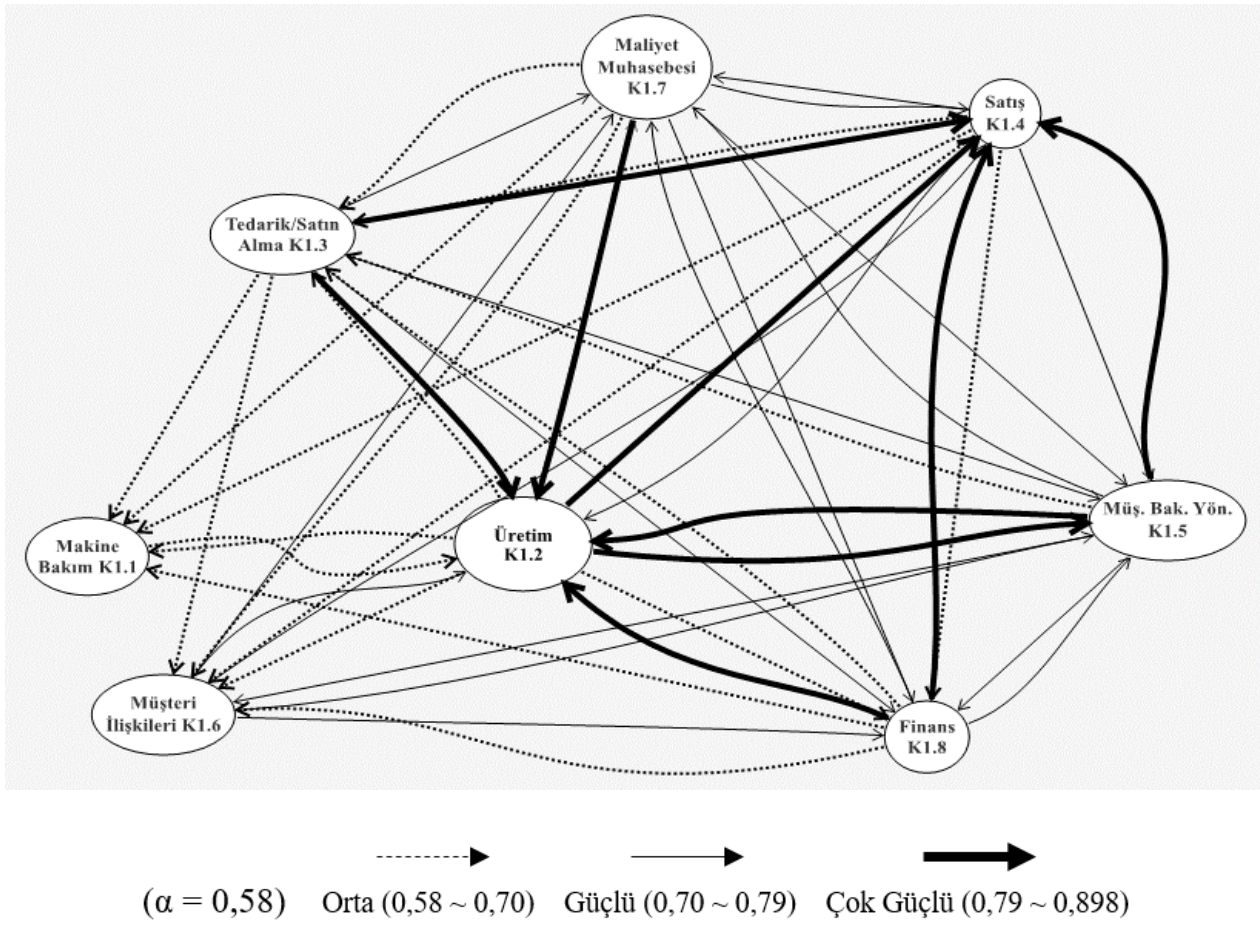

\section{DEĞERLENDİRME VE SONUÇ}

Çalışmanın BAHY uygulaması sonucunda ana kriterlerin ikili karşılaştırmalarına göre yazılım özellikleri (K1) ve maliyet (K1) en önemli kriterler olarak belirlenmiştir. Alternatiflerin kriterle göre değerlendirilmesi sonucunda ise A alternatifinin \%62, B alternatifinin ise \%38 değerlerine sahip olduğu ortaya çıkmıştır. Bu sonuçlara göre işletme KKP yazılımı olarak en yüksek değere sahip A alternatifini seçmesi doğru bir karar olacaktır.

Çalışmanın BDY uygulamasında ana kriterler ve yazılım özelliklerinin alt kriterleri değerlendirilmiştir. Sadece yazılım özelliklerinin alt kriterlerinin değerlendirilmesinin başlıca sebebi KKP yazılım uygulamalarının başarısında bu kriterlerin çok önemli bir payı olması ve işletme süreçlerini doğrudan temsil etmesidir. Ayrıca BAHY uygulaması sonucunda yazılım özellikleri en önemli ana kriterlerden biri olarak ortaya çıkmıştır.

Ana kriterlerin değerlendirilmesi sonucunda D-R değerlerine göre yazılım özelliklerinin ve firma özelliklerinin etkileyen grubunda, maliyet ve kurulum süresinin ise etkilenen grubunda olduğu ortaya çıkmıştır. $\mathrm{Bu}$ nedenle KKP yazılımının hem seçim hem de kurulum süreçlerinde yazılım ve firma özelliklerine dikkat edilmelidir. Ayrıca yazılım özelliklerinin alt kriterleri incelendiğinde ise tedarik/satın alma, müşteri bakım yönetimi, finans ve esneklik etkileyen grubunda; makine bakım modülü, üretim modülü, müşteri ilişkileri, 
maliyet muhasebesi ise etkilenen grubunda olarak belirlenmiştir. En yüksek değere sahip esneklik kriteri diğer kriterler üzerinde önemli bir etkiye sahiptir. Bu anlamda seçilecek olan yazılımın esneklik konusunda kabiliyeti ön plana çıkmaktadır. Ayrıca D+R değerlerine göre bu kriterler arasında en önemli iki kriter üretim ve müşteri bakım modülü kriterleridir. İşletmenin iki ana faaliyetini destekleyecek olan bu iki modül hem seçim hem kurulum aşamalarında ön planda olmalıdır.

Ek olarak strateji haritası incelendiğinde tedarik/satın alma üretimi, üretim satış1, maliyet muhasebesi üretimi, tedarik/satın alma satışı, müşteri bakım yönetimi satışı, finans satışı, finans üretimi ve üretim ile müşteri bakım yönetimi karş1lıklı olarak birbirini çok güçlü olarak etkilediği görülmektedir. Özellikle kurulum süreçlerinde KKP yazılımının iş süreçlerine uygulanmasında strateji haritasındaki bu ilişkilerin dikkatli bir şekilde ele alınması projenin başarısında önemli bir rol oynayacaktır.

\section{KAYNAKÇA}

Abdel-Kader, M. G., Ve Dugdale, D. (2001). Evaluating Investments In Advanced Manufacturing Technology: A Fuzzy Set Theory Approach. The British Accounting Review, 33(4), 455489.

Abdullah, L., ve Zulkifli, N. (2015). Integration Of Fuzzy AHP And İnterval Type-2 Fuzzy DEMATEL: An Application To Human Resource Management. Expert Sytem With Applications, 42, 4397-4409.

Akça, Y., Ve Özer, G. (2013). Kullanıcı Özelliklerinin Kurumsal Kaynak Planlaması Uygulama Başarısına ve Algılanan Organizasyonel Performansa Etkisi. Journal Of Yaşar University, 30(8), 4966-4984.

Aksakal, E., ve Dağdeviren, M. (2010). ANP ve DEMATEL Yöntemleri İle Personel Seçimi Problemine Bütünleşik Bir Yaklaşım. Gazi Üniversitesi Mühendislik Mimarlık Fakültesi Dergisi, 25(4), 905-913.

Alanbay, O. (2005). ERP Selection Using Expert Choice Software. ISAHP Honolulu, Hawai.

Altan, Ş., ve Aydın, E. K. (2015). Bulanık DEMATEL ve Bulanık TOPSİS Yöntemleri İle Üçüncü Parti Lojistik Firma Seçimi İçin Bütünleşik Bir Model Yaklaşımı. Süleyman Demirel Üniversitesi İ̈BF Dergisi, 20(3), 99-119.

Amalnick, M. S., Ansarinejad2, A., Nargesi, S.-M., ve Taheri, S. (2011). New Perspective To ERP Critical Success Factors: Priorities And Causal Relations Under Fuzzy Environment. The Journal Of Mathematics And Computer Science, 2(1), 160-170.

Ayağ, Z., ve Özdemir, R. G. (2006). A Fuzzy AHP Approach To Evaluating Machine Tool Alternatives. Journal Of Intellectual Manufacturing, 17, 179-190.

Baki, B., ve Çakar, K. (2005). Determining The ERP Package-Selecting Criteria: The Case Of Turkish Manufacturing Companies. Business Process Management Journal, 11(1), 75-86.

Bernroider, E., ve Koch, S. (2001). ERP Selection Process İn Midsize And Large Organizations. Business Process Management Journal, 7(3), 251-257.

Burgués, X., Xavier, I., Joan, F., ve Pastor, A. (2000). Formalising ERP Selection Criteria. In Proceedings Of The Tenth International Workshop On Software Specification And Design. Business Process Management Journal, 7(3), 251 - 257

Büyüközkan, G., ve Çiftçi, G. (2012). A Novel Hybrid MCDM Approach Based On Fuzzy DEMATEL, Fuzzy ANP And Fuzzy TOPSIS To Evaluate Green Suppliers. Expert Systems With Applications, 39, 3000-3011.

Cebeci, U. (2009). Fuzzy AHP-Based Decision Support System For Selecting ERP Systems İn Textile İndustry By Using Balanced Scorecard. Expert Systems With Applications, 36, 8900-8909. 
Yeşim D. Özkan Özen \& Aydın Koçak / Bulanık Analitik Hiyerarşi ve Bulanık Dematel Yöntemleri Kullanılarak Kurumsal Kaynak Planlaması Yazılım Seçimi ve Değerlendirilmesi

Chang, A.-Y., ve Chen, C.-J. (2011). Analysing Critical Factors Of Introducing RFID İnto An Enterprise- An Application Of AHP And DEMATEL Method. Ibternational Journal of Industrial Engineering, 18(7), 323-334.

Chang, B., Chang, C.W., ve Wu, C.-H. (2011). Fuzzy DEMATEL Method For Developing Supplier Selection Criteria. Expert Sytems With Applications, 38, 1850-1858.

Chang, D.-Y. (1996). Application Of The Extend Analysis Method On Fuzzy AHP. European Journal Of Operational Research, 95, 649-655.

Chou, Y.C., Sun, C.C., ve Yen, H.Y. (2012). Evaluating The Criteria For Human Resource For Science And Technology (HRST) Based On An İntegrated Fuzzy AHP And Fuzzy DEMATEL Approach. Applied Soft Computing, 12, 64-71.

Dağdeviren, M. (2007). Performans Değerlendirme Sürecinin Bulanık AHP İle Bütünleşik Modellenmesi. Mühendislik Ve Fen Bilimleri Dergisi, 25(3), 268-282.

Edward Bernroider Stefan Koch, (2001),"ERP selection process in midsize and large organizations",

Jahanshahi, H., Farhadzareh, B., Fotuhi, H., Mokhtari, A. G., ve Bagher, M. (2013). A New Algorithm For ERP System Selection Based On Fuzzy DEMATEL Approach. Advances In Environmental Biology, 7(9), 2509-2521.

Jassbi, J., Mohamadnejad, F., ve Nasrollahzadeh, H. (2011). A Fuzzy DEMATEL Framework For Modeling Cause And Effect Relationships Of Strategy Map. Expert Systems With Applications, 38(5), 5967-5973.

Kahraman, C., Cebeci, U., ve Ruan, D. (2004). Multi-Attribute Comparison Ofcatering Service Companies Using Fuzzy AHP: The Case Of Turkey. International Journal Of Production Economics, 87, 171-184.

Karaarslan, N., ve Gundogar, E. (2009). An Application For Modular Capability-Based ERP Software Selection Using AHP Method. The International Journal Of Advanced Manufacturing Technology, 42, 1025-1033.

Karaoğlan, S., ve Şahin, S. (2016). DEMATEL Ve AHP Yöntemleri İle İşletmelerin Satın Alma Problemine Bütünleşik Bir Yaklaşım, DSLR Kamera Örneği. Iş̧letme Araştırmaları Dergisi, 8(2), 359-375.

Karsak, E. E., \& Özogul, C. O. (2009). An integrated decision making approach for ERP system selection. Expert systems with Applications, 36(1), 660-667.

Kılıç, H. S., Zaim, S., ve Delen, D. (2014). Development Of A Hybrid Methodology For ERP System Selection: The Case Of Turkish Airlines. Decision Support Systems, 66, 82-92.

Kilic, H. S., Zaim, S., \& Delen, D. (2015). Selecting "The Best" ERP system for SMEs using a combination of ANP and PROMETHEE methods. Expert Systems with Applications, 42(5), 2343-2352.

Kocak, A. (2003). Yazılım Seçiminde Analitik Hiyerarşi Yöntemi Yaklaşımı Ve Bir Uygulama. Ege Academic Review, 3(1), 67-77.

Kumar, A., ve Dash, M. K. (2016). Using DEMATEL To Construct Influential Network Relation Map Of Consumer Decision-Making İn E-Marketplace. International Journal Of Business Information Systems, 21(1), 48-72.

Kwong, C., ve Bai, H. (2003). Determining The Importance Weights For The Customer Requirements İn QFD Using A Fuzzy AHP With An Extent Analysis Approach. IIE Transactions, 35(7), 619-626.

Leung, L., ve Cao, D. (2000). On Consistency And Ranking Of Alternatives İn Fuzzy AHP. European Journal Of Operational Research, 124, 102-113.

Lien, C. T., \& Liang, S. K. (2005). An ERP system selection model with project management viewpoint-A fuzzy multi-criteria decision-making approach. International Journal of the Information Systems for Logistics and Management, 1(1), 39-46.

Liou, T. S., ve Wang, M. J. J. (1992). Ranking Fuzzy Numbers With İntegral Value. Fuzzy Sets And Systems, 50(3), 247-255.

Opricovic, S., ve Tzeng, G.-H. (2003). Defuzzification Within A Multicriteria Decision Model. International Journal Of Uncertaintry, Fuziness And Knowledge-Based Systems, 11(05), 635-652. 
Perera, H. S. C., ve Costa, W. K. R. (2008). Analytic Hierarchy Process For Selection Of ERP Software For Manufacturing Companies. Vision, 12(4), 1-11.

Ranjan, S., Jha, V. K., ve Pal, P. (2016). A Strategic And Sustainable Multi-Criteria Decision Making Framework For ERP Selection İ OEM. International Journal Of Applied Engineering Research, 11(3), 1916-1926.

Reuther, D., ve Chattopadhyay, G. (2004). Critical Factors For Enterprise Resources Planning System Selection And İmplementation Projects Within Small To Medium Enterprises. Engineering Management Conference (S. 851-855). IEEE International.

Rouhani, A., Ashrafi, A., ve Afshari, S. (2013). Segmenting Critical Success Factors For ERP Implementation Using Integrated Fuzzy AHP And Fuzzy DEMATEL Approach. World Applied Sciences Journal, 22(8), 1066-1079.

Saaty, T. L. (1986). Axiomatic Foundation Of The Analytic Hierarchy Process. Management Science, 32(7), 841-855.

Saaty, T. L. (1990). How To Make A Decision: The Analytic Hierarchy Process. European Journal Of Operational Research, 48(1), 9-26.

Shuai, J., ve Kao, C. Y. (2008). Building An Effective ERP Selection System For The Technology İndustry. Industrial Engineering And Engineering Management (S. 989-993). IEEE.

Silva, J., Goncalves, J. J., Fernandes, J. A., ve Cunha, M. M. (2013). Criteria For ERP Selection Using An AHP Approach. Information Systems And Technologies (S. 1-6). IEEE.

Tolga, E., Demircan, M. L., ve Kahraman, C. (2005). Operating System Selection Using Fuzzy Replacement Analysis And Analytic Hierarchy Process. International Journal of Production Economics, 97, 89-117.

Tsai, W. H., ve Chou, W. C. (2009). Selecting Management Systems For Sustainable Development In Smes: A Novel Hybrid Model Based On DEMATEL, ANP, And ZOGP. Expert Systems With Applications, 36(2), 1444-1458.

Tzeng, G. H., Chiang, C. H., \& Li, C. W. (2007). Evaluating intertwined effects in e-learning programs: A novel hybrid MCDM model based on factor analysis and DEMATEL. Expert systems with Applications, 32(4), 1028-1044.

Vatansever, K., ve Uluköy, M. (2013). Kurumsal Kaynak Planlaması Sistemlerinin Bulanık AHP Ve Bulanık MOORA Yöntemleriyle Seçimi: Üretim Sektöründe Bir Uygulama. CBÜ Sosyal Bilimler Dergisi, 11(2), 274-273.

Wei, C. C., Chien, C. F., ve Wang, M. J. J. (2005). An AHP-Based Approach To ERP System Selection. International Journal Of Production Economics, 96, 47-62.

Wei, C. C., ve Wang, M. J. J. (2004). A Comprehensive Framework For Selecting An ERP System. International Journal Of Project Management, 22, 161-169.

$\mathrm{Wu}, \mathrm{H}$. Y. (2012). Constructing A Strategy Map For Banking İnstitutions With Key Performance İndicators Of The Balanced Scorecard. Evaluation And Program Planning, 35(3), 303320.

Wu, H.-H., ve Tsai, Y.-N. (2012). An İntegrated Approach Of AHP And DEMATEL Methods In Evaluating The Criteria Of Auto Spare Part İndustry. International Journal Of System Science, 43(11), 2114-2124.

Wu, W. W., ve Lee, Y. (2007). Developing Global Managers' Competencies Using The Fuzzy DEMATEL Method. Expert Systems With Applications, 32(2), 499-507.

Yang, J. L., ve Tzeng, G. H. (2011). An Integrated MCDM Technique Combined With DEMATEL For A Novel Cluster-Weighted With ANP Method. Expert Systems With Applications, 38(3), 1417-1424.

Yang, Y. P. O., Shieh, H. M., Leu, J. D., ve Tzeng, G. H. (2008). A Novel Hybrid MCDM Model Combined With DEMATEL And ANP With Applications. International Journal of Operations Research, 5(3), 160-168.

Zadeh, L. A. (1965). Fuzzy Sets. Information And Control,, 8(3), 338-353. 
EK 1: KKP Seçim Literatür Özeti

\begin{tabular}{|c|c|c|c|}
\hline $\begin{array}{l}\text { Yazar Adı ve } \\
\text { Yıl }\end{array}$ & $\begin{array}{l}\text { Kullanılan } \\
\text { Metot }\end{array}$ & Ana Kriterler (1. Seviye) & Alt Kriterler (2. Seviye) \\
\hline $\begin{array}{l}\text { Xavier } \\
\text { Burgués Illa, } \\
\text { Xavier Franch } \\
\text { ve Joan Antoni } \\
\text { Pastor (2000) }\end{array}$ & SHERPA & $\begin{array}{ll}\text { 1. } & \text { Fonksiyonellik } \\
\text { 2. } & \text { Ana hedef } \\
\text { 3. } & \text { Uyumluluk } \\
\text { 4. } & \text { Kişiselleştirmeye ve } \\
\text { diğer sistemlerle } \\
\text { birlikte çalışmaya } \\
\text { uygunluk } \\
\text { 5. Özel destekler }\end{array}$ & X \\
\hline $\begin{array}{l}\text { Edward } \\
\text { Bernroider ve } \\
\text { Stefan Koch } \\
(2001)\end{array}$ & Anket & 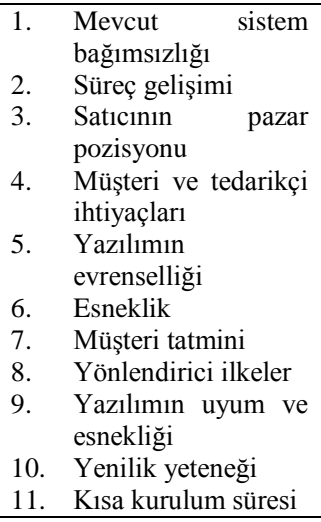 & e \\
\hline Koçak (2003) & AHY & $\begin{array}{ll}\text { 1. } & \text { Teknik Özellikler } \\
\text { 2. Uygulamaya Yönelik } \\
\text { Özellikler } \\
\text { 3. Yazılım Firmasında } \\
\text { Aranan Özellikler } \\
\text { 4. } \\
\text { Maliyet }\end{array}$ & $\begin{array}{l}\text { Veri Tabanı (1.1), Özel. İhtiyaç Karşılama (1.2), } \\
\text { Kullanic1 Dostu (1.3), Raporlama (1.4), } \\
\text { Türkçeleştirme (1.5), M.U.Ol (1.6), İnternet } \\
\text { Tabanlı (1.7), Uygulama ve Kurulum. Süresi (1.8), } \\
\text { Ort. ve B. Ölç. İsslt. (2.1), Barkod. Sistemi. Desteği. } \\
\text { (2.2), Uyarı Sistemi (2.3), Para Birim. Desteği } \\
\text { (2.4), İş Süreç Esnekliği (2.5), Modül Entgrasyonu } \\
\text { (2.6), Enfl. Muh. (2.7), Eğitim. ve Danışmanlık } \\
\text { Hizmeti (3.1), Yerlş. ve İşbrl (3.2), Referans (3.3), } \\
\text { Ürün Geliştirme (3.4) }\end{array}$ \\
\hline $\begin{array}{l}\text { D. Reuther've } \\
\text { G. } \\
\text { Chattopadhyay } \\
\text { (2004) }\end{array}$ & Anket & $\begin{array}{ll}\text { 1. } & \text { Sistem } \\
& \text { fonksiyonellik } \\
& \text { gereksinimleri } \\
\text { 2. } & \text { İşletme öncelikleri } \\
\text { 3. } & \text { Maliyet öncelikleri } \\
\text { 4. } & \text { Esneklik } \\
\text { 5. } & \text { Ölçeklendirilebilirlik } \\
\text { 6. } & \text { Özel kriterler } \\
\end{array}$ & ( \\
\hline $\begin{array}{l}\text { Chun-Chin } \\
\text { Wei ve Mao- } \\
\text { Jiun J. Wang } \\
(2004)\end{array}$ & $\begin{array}{l}\text { Bulanık Küme } \\
\text { Teorisi }\end{array}$ & $\begin{array}{ll}\text { 1. } & \text { Toplam Maliyet, } \\
\text { 2. } & \text { Kurulum Süresi, } \\
\text { 3. Faydalar, } \\
\text { 4. Riskler, } \\
\text { 5. Stratejik Uyum, } \\
\text { 6. } \\
\text { Fonksiyonlar Ve } \\
\text { 7eknoloji, } \\
\text { 7. Satıcı Yetenekleri, } \\
\end{array}$ & $\begin{array}{l}\text { Amaç ve vizyon uyumu (5.1), Lokal çevresel } \\
\text { gereksinimler (5.2), Güvenilirlik ve kalite (6.1), } \\
\text { Kullanıı dostluğ (6.2), Gelişme ve } \\
\text { güncelleşmeler (6.3), Işlevsel uyum (6.4), Ar-Ge } \\
\text { teknolojisi (7.1), Uygulama ve servis kabiliyeti } \\
\text { (7.2), Danışmanlık hizmeti (7.3), Eğitim desteği } \\
\text { (7.4), Finansal durum (8.1), Referanslar (8.2) }\end{array}$ \\
\hline
\end{tabular}




\begin{tabular}{|c|c|c|c|}
\hline & & 8. $\quad$ Satıc1 Ünü & \\
\hline $\begin{array}{l}\text { Öykü Alanbay } \\
(2005)\end{array}$ & AHY & $\begin{array}{ll}\text { 1. } & \text { Teknoloji ile ilişkili } \\
\text { 2. } & \text { Kullanıcı ile ilişkili } \\
\text { 3. } & \text { Satıcı ile ilişkili }\end{array}$ & 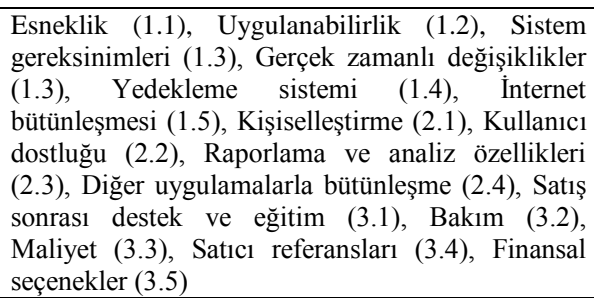 \\
\hline $\begin{array}{l}\text { Birdoğan Baki } \\
\text { ve Kemal } \\
\text { Çakar (2005) }\end{array}$ & Anket & $\begin{array}{ll}\text { 1. } & \text { Fonksiyonellik } \\
\text { 2. } & \text { Teknik özellikler } \\
\text { 3. } & \text { Maliyet, } \\
\text { 4. } & \text { Hizmet ve destek, } \\
\text { 5. } & \text { Uzak görüslülük, } \\
\text { 6. } & \text { Sistem güvenilirliği, } \\
\text { 7. } & \text { Rekabet üstünlüğü } \\
\text { 8. } & \text { Kişiselleştirme } \\
& \text { kolaylığ1 } \\
\text { 9. Satıcının pazar } & \text { pozisyonu } \\
\text { 10. } & \text { İsletme } \\
& \text { uyumluluk ile } \\
\text { 11. } & \text { Satıcı bilgisi } \\
\text { 12. } & \text { Referanslar } \\
\text { 13. } & \text { Kurulum süresi } \\
\text { 14. } & \text { Modül entegrasyonu }\end{array}$ & e \\
\hline $\begin{array}{l}\text { Chi-Tai Lien } \\
\text { ve Shing-Ko } \\
\text { Liang (2005) }\end{array}$ & Bulanık AHP & 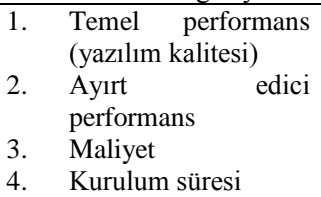 & $\begin{array}{l}\text { Ürün işlemleri (1.1), ürün yapılandırması (1.2), } \\
\text { ürün dönüşüüü (1.3), pazar payı (2.1), iş gücü } \\
\text { gereksinimi (2.2), sertifikasyon sistemi (2.3), } \\
\text { işbirliği eğilimi (2.4), eğitim (2.5), yazılım maliyeti } \\
\text { (3.1), kurulum maliyeti (3.2) }\end{array}$ \\
\hline $\begin{array}{l}\text { Chun-Chin } \\
\text { Wei, Chen-Fu } \\
\text { Chien ve Mao- } \\
\text { Jiun J. Wang } \\
\text { (2005) }\end{array}$ & AHY & $\begin{array}{ll}\text { 1. } & \text { Maliyet } \\
\text { 2. } & \text { Kurulum süresi, } \\
\text { 3. } & \text { Fonksiyonellik, } \\
\text { 4. } & \text { Kullanıcı dostu ara } \\
& \text { yüz ve işlemleri, } \\
\text { 5. } & \text { Sistem esnekliği } \\
\text { 6. } & \text { Sistem güvenilirliği } \\
\text { 7. } & \text { Referanslar } \\
\text { 8. } & \text { Teknik yeterlilik } \\
\text { 9. Satış sonrası } \\
\text { hizmetler }\end{array}$ & 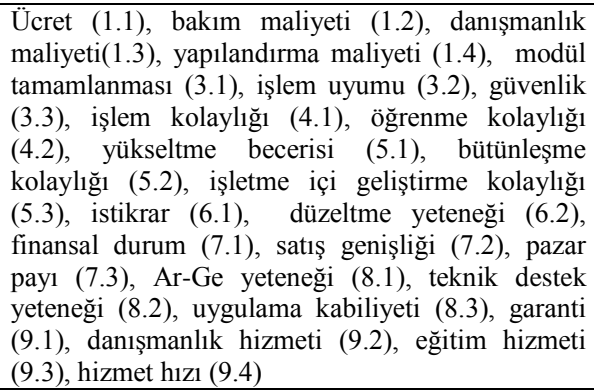 \\
\hline $\begin{array}{l}\text { H.S.C. Perera; } \\
\text { W.K.R. Costa } \\
\text { (2008) }\end{array}$ & AHY & $\begin{array}{ll}\text { 1. } & \text { İşletme stratejisi } \\
\text { 2. } & \text { Değişim yönetimi ve } \\
& \text { uygulanabilirlik } \\
\text { 3. } & \text { Risk } \\
\text { 4. } & \text { Fonksiyonel uyum } \\
& \text { ve esneklik } \\
\text { 5. } & \text { Maliyet } \\
\text { 6. } & \text { Teknoloji } \\
\text { 7. } & \text { Satıc1 durumu ve } \\
& \text { satış sonrası anlaşma } \\
\end{array}$ & 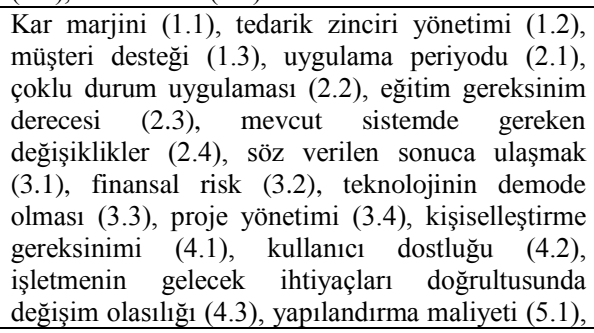 \\
\hline
\end{tabular}




\begin{tabular}{|c|c|c|c|}
\hline & & & $\begin{array}{l}\text { tüm lisansları içeren satın alma maliyeti (5.2), } \\
\text { eğitim maliyeti (5.3), güncelleme maliyeti (5.4), } \\
\text { ERP kullanan sistemin teknoloji durumu (6.1), } \\
\text { donanım gereksinimleri (6.2), geliştirmeler için } \\
\text { limitler (6.3), yerel satıcının teknoloji durumu } \\
\text { (7.1), destekleyici çalşanlar (7.2), geçmiş kayıtlar } \\
\text { (7.3), ilgili çalışanların eğitimi (7.4), yerinde bakım } \\
\text { (7.5) }\end{array}$ \\
\hline $\begin{array}{l}\text { J. J. Shuai ve } \\
\text { C. Y. Kao } \\
(2008)\end{array}$ & DEMATEL & $\begin{array}{ll}\text { 1. } & \text { Risk } \\
\text { 2. } & \text { Toplam maliyet } \\
\text { 3. } & \text { Fonksiyonellik } \\
\text { 4. } & \text { Esneklik } \\
\text { 5. } & \text { Teknik yeterlilik } \\
\text { 6. } & \text { Satıcı hizmeti } \\
\end{array}$ & (2) \\
\hline $\begin{array}{l}\text { Nevin } \\
\text { Karaarslan; } \\
\text { Emin } \\
\text { Gundogar } \\
(2009)\end{array}$ & AHY & 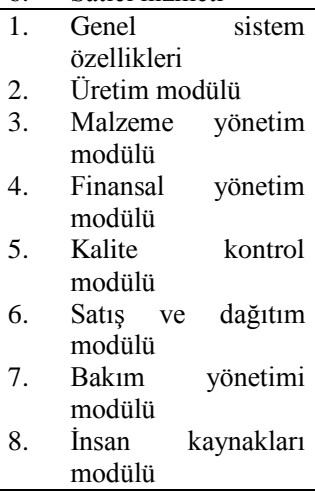 & $\mathrm{X}$ \\
\hline $\begin{array}{l}\text { Ertuğrul } \\
\text { Karsak; Okan } \\
\text { Özoğul (2009) }\end{array}$ & $\begin{array}{l}\text { QFD, Bulanık } \\
\text { Lineer } \\
\text { Regresyon ve } \\
0-1 \quad \text { Hedef } \\
\text { Programlama }\end{array}$ & $\begin{array}{l}\text { 1. Müşteri beklentileri } \\
\text { 2. } \quad \text { ERP özellikleri }\end{array}$ & $\begin{array}{l}\text { Toplam satın alma maliyeti (1.1), sisteme } \\
\text { fonksiyonel uyum (1.2), kullanıcı dostluğu (1.3), } \\
\text { esneklik (1.4), satıcnın itibarı (1.5), hizmet ve } \\
\text { destek kalitesi (1.6), desteklenen ihtiyaçların } \\
\text { yüzdesi (2.1), kişiselleştirme ile desteklenen } \\
\text { ihtiyaçların yüzdesi (2.2), müssteri sayısı (2.3), } \\
\text { satıcının toplam kazancı (2.4), çözüm ortaklarının } \\
\text { sayısı (2.5), ortalama kullanıı eğitim süresi (2.6), } \\
\text { satıcının işlem yaptı̆ı̆ ülkeler (2.7) }\end{array}$ \\
\hline $\begin{array}{l}\text { Joaquim P. } \\
\text { Silva, José } \\
\text { António } \\
\text { Fernandes, } \\
\text { José Joaquim } \\
\text { Gonçalves, } \\
\text { Maria } \\
\text { Manuela } \\
\text { Cunha (2013) }\end{array}$ & AHY & $\begin{array}{ll}\text { 1. } & \text { KKP satıcisı } \\
\text { 2. } & \text { KKP yazılım paketi }\end{array}$ & 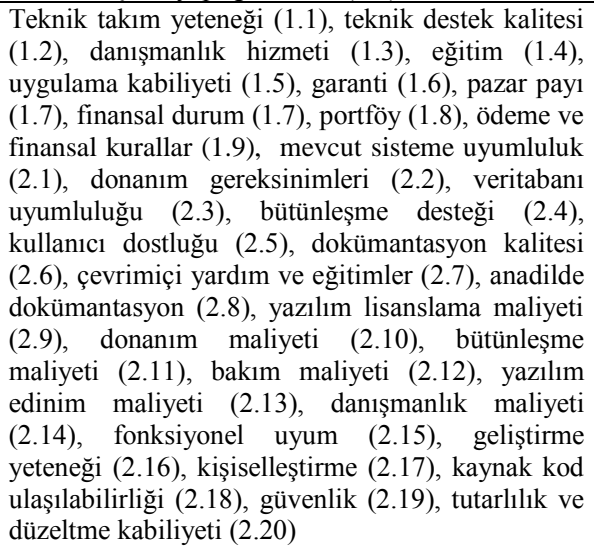 \\
\hline
\end{tabular}




\begin{tabular}{|c|c|c|c|}
\hline $\begin{array}{l}\text { Kemal } \\
\text { Vatansever ve } \\
\text { Metin Uluköy } \\
(2013)\end{array}$ & $\begin{array}{l}\text { Bulanık AHY } \\
\text { ve Bulanık } \\
\text { MOORA }\end{array}$ & $\begin{array}{ll}\text { 1. } & \text { Toplam maliyet } \\
\text { 2. } & \text { Fonksiyonellik } \\
\text { 3. } & \text { Sistemin Esnekliği } \\
\text { 4. } & \text { Sistemin } \\
& \text { güvenilirliği } \\
\text { 5. } & \text { Uygulama zamanı } \\
\text { 6. } & \text { Kullanım kolaylığ } 1 \\
\end{array}$ & $X$ \\
\hline $\begin{array}{ll}\text { Hüseyin } & \\
\text { Selçuk K1lıç, } \\
\text { Selim } & \text { Zaim, } \\
\text { Dursun } & \text { Delen } \\
(2014) & \\
\end{array}$ & $\begin{array}{l}\text { Bulanık AHY } \\
\text { ve Bulanık } \\
\text { TOPSISS }\end{array}$ & $\begin{array}{ll}\text { 1. } & \text { Teknik kriterler } \\
\text { 2. } & \text { Kurumsal kriterler } \\
\text { 3. } & \text { Finansal kriterler }\end{array}$ & 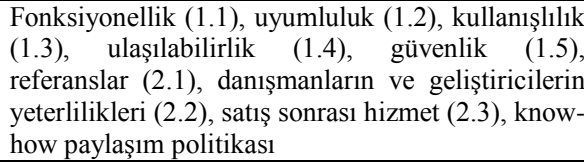 \\
\hline $\begin{array}{ll}\text { Hüseyin } & \\
\text { Selçuk K1lıç, } \\
\text { Selim } & \text { Zaim, } \\
\text { Dursun } & \text { Delen } \\
(2015) & \end{array}$ & $\begin{array}{lr}\text { ANP ve } \\
\text { PROMETHEE }\end{array}$ & $\begin{array}{ll}\text { 1. } & \text { İşletme kriterleri } \\
\text { 2. } & \text { Maliyet kriterleri } \\
\text { 3. } & \text { Teknik kriterler }\end{array}$ & $\begin{array}{l}\text { Vizyon (1.1), marka imajı (1.2), referanslar (1.3), } \\
\text { pazar pozisyonu (1.4), } \\
\text { Satın alma maliyeti (2.1), uygulama maliyeti (2.2), } \\
\text { hizmet ve destek maliyeti (2.3), fonksiyonellik } \\
\text { (3.1), güvenilirlik (3.2), uyumluluk (3.3), modüller } \\
\text { arası entegrasyon (3.4) }\end{array}$ \\
\hline $\begin{array}{l}\text { Shree Ranjan, } \\
\text { Vijay Kumar } \\
\text { Jha, Pralay Pal } \\
\text { (2016) }\end{array}$ & AHY & $\begin{array}{ll}\text { 1. } & \text { Fonksiyon } \\
\text { 2. } & \text { Maliyet } \\
\text { 3. } & \text { Teknoloji } \\
\text { 4. } & \text { Satıcı } \\
\text { 5. } & \text { Yazılım kalitesi }\end{array}$ & $\begin{array}{l}\text { Finansa (1.1), fiyatlandırma (1.2), malzeme } \\
\text { yönetimi (1.3), üretim planlama (1.4), kalite } \\
\text { yönetimi (1.5), satış ve dağıtım (1.6), insan } \\
\text { kaynakları (1.7), lisans (2.1), uygulama } \\
\text { bakım (2.3), yükseltme (2.4), yapı (2.5), işlem } \\
\text { harcamaları (2.6), fonksiyonel entegrasyon } \\
\text { üçüncü partiye açıklı (3.2), esneklik (3.3), } \\
\text { hassaslı (3.4), bulut erişimi (3.5), sosyal medya } \\
\text { erişimi (3.6), mobil erişim (3.7), gelecek garantisi } \\
\text { ve süreklilik (3.8), özelleştirilmiş bilgi (4.1), } \\
\text { müşteri referansları (4.2), uygulama metodolojileri } \\
\text { (4.3), kurumsal felsefe (4.4), pazar payı (4.5), } \\
\text { hizmet ve destek (4.6), ürün güvenilirliği (5.1), } \\
\text { ürün bakımı (5.2), karşılıklı çalışabilirlik (5.3), } \\
\text { ürün ölçeklenebilirliği (5.4), ürün taşınabilirliği } \\
\text { (5.5), ürün yeniden kullanılabilirliği (5.6) }\end{array}$ \\
\hline
\end{tabular}


EK 2: KKP Seçim Hiyerarşisi

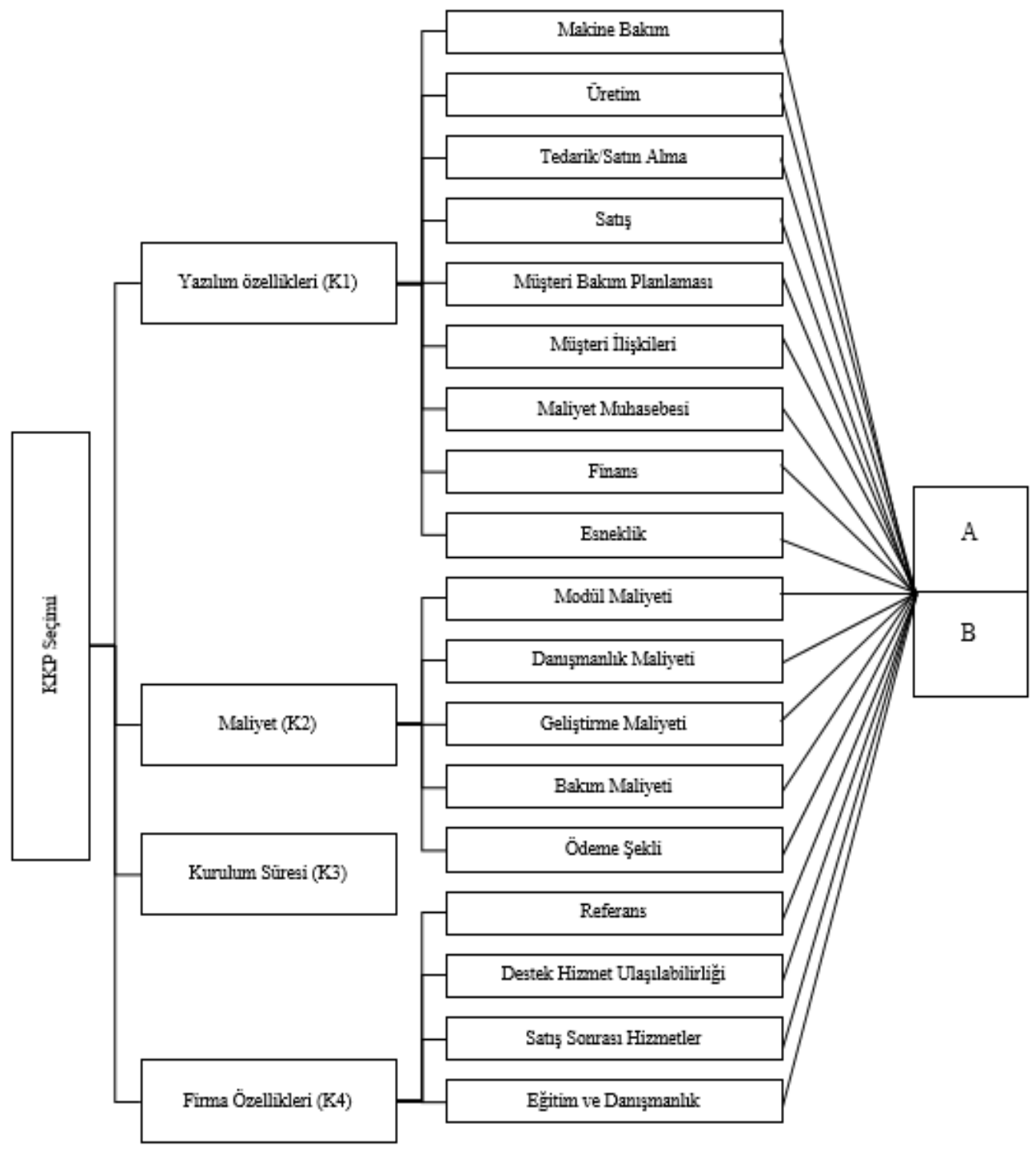




\section{SUMMARY}

In last two decades, factors such as globalization, developments in management information systems, improvements in manufacturing systems, increased competition, shortened product life cycles and changes in customer expectations have led to increased complexity in business processes. Therefore, in order to manage this complexity, while minimizing costs, it is a necessity for companies to use Enterprise Resource Planning (ERP).

ERP selection is a popular topic in the literature. Especially using Multi Criteria Decision Making (MCDM) methods to evaluate criteria and making a proper decision for companies are highly preferred by researchers. In this study, fuzzy AHP and fuzzy DEMATEL methods were used together with different purposes. Implementation of the study was conducted in a small size manufacturing company and two ERP firms were evaluated as alternatives. In total 4 main criteria and 18 sub-criteria were presented as the result of meetings with company manager. All criteria and sub-criteria include detailed needs and features of the company. In the implementation part, firstly, fuzzy AHP method was used to evaluate the criteria according to alternatives and make a decision. Secondly, fuzzy DEMATEL method was used to present the causal relationship between main criteria and the sub-criteria of software properties.

According to the result of fuzzy AHP method, final scores of the alternatives were $62 \%$ and $38 \%$ respectively. Therefore, it is suggested to the company to select the first alternative. Moreover, software properties and cost were found as the most important criteria for the company.

In addition, results of the fuzzy DEMATEL method showed that, while software properties and company properties are in the cause group; cost and setup time are in the effect group. Fuzzy DEMATEL method was also used to evaluate sub-criteria of software properties, since these sub-criteria have a significant effect on the success of ERP implementation. Results showed that; supply/purchase, customer maintenance management, finance and flexibility are in the cause group. On the other hand, maintenance, production, customer relations and cost accounting are in the effect group. Moreover, importance order was found consistent with company's field of activity. Manufacturing and customer maintenance were found as the most important ones according to the results of the fuzzy DEMATEL. By using these results, a detailed strategy map was constructed to guide the company during the transition process of ERP implementation and usage. 